\author{
Tefsir Araştırmaları Dergisi \\ The Journal of Tafsir Studies \\ مجلة تادر للدبدوث التفسديرية \\ www.dergipark.org.tr/tader
}

\title{
Kur'an Meallerinde Bağlama Riayet Etmenin Önemi
}

\begin{abstract}
Abdulkadir KARAKUŞ*
$\ddot{O} z$

İlk dönemlerde Hz. Peygamber'in hayatta olduğu süre içerisinde Kur'an'ın anlaşılması ve yorumlanması hususunda herhangi bir problem görünüyor olmasa da Hz. Peygamber'den sonraki dönemlerden başlayarak günümüze kadar geçen ve hala da devam eden süreç içerisinde, bu kitabın doğru anlaşılması ve yorumlanması konusunda birtakım sıkıntılar meydana gelmiştir. Bu ilmin önemli konularından bir tanesi de eskilerin "siyâk" olarak isimlendirdikleri, sözün hangi şartlarda ve hangi ihtiyaca cevap olmak üzere söylendiği "bağlam" meselesidir. Bağlama gereğince önem verilmemesinden dolayı da ayetin gerçek anlamından uzaklaşıp farklı manalara kapı aralanabilmiştir. Kur'an'ı anlamada bağlam göz ardı edildiğinde, doğru yoruma ulaşmak çoğu zaman imkânsız hale gelmiştir. Bu araştırmada, ayetlerin doğru bir şekilde anlaşılabilmesi ve yorumlanabilmesi için bağlamın öneminin ortaya konulmasına, Kur'an meallerinde bu hususa ne ölçüde riayet edildiğinin belirlemesine ve konunun ilgili ayetlerden örneklerle izah edilmesine gayret edilecektir. Bunu yaparken de ayetlerin anlamının, yaygın kullanıldığ düşünülen Kur'an meallerinden bazılarıyla mukayeseler yapılacak ve böylece daha zengin anlamlar ortaya konmaya çalış1lacaktır.
\end{abstract}

Anahtar Kelimeler: Tefsir, Kur’an, Mealler, Siyâk, Bağlam.

\begin{abstract}
There is no problem in the understanding and interpretation of the Qur'an during the period when the Prophet was still alive. However, there have been some problems in the correct understanding and interpretation of this book since the period after the Prophet and to the present day. One of the important issues of this science is the context issue under which conditions and the need are mentioned. Due to the lack of importance due to the context, it was possible to move away from the real meaning of the verse and open the door to different meanings. When the context is ignored in understanding the Qur'an, it is often impossible to reach the correct interpretation. In this study, we will try to reveal the importance of the context in order to be able to understand and interpret the verses correctly, to determine the extent to which this point is observed in the Qur'an and to explain the subject with examples from the related verses.
\end{abstract}

The Importance of Context in Translating of the Qur'an

Keywords: Exegesis, Qur'an, Qur'an translations, Siyâq, Context.

* Dr. Öğr. Üyesi, Siirt Üniversitesi, İlahiyat Fakültesi, Tefsir Anabilim Dalı. konevi61@hotmail.com.

ORCID: https://orcid.org/0000-0003-2387-2402.

Bu makale "iThenticate" intihal tarama programında taranmış ve intihal içermediği tespit edilmiştir.

Gönderim Tarihi: 25 Ocak 2020. Kabul Tarihi: 02 Nisan 2020. Yayın Tarihi: 30 Nisan 2020.

Makale Tipi: Araştırma Makalesi.

DOI Numarasi: $10.31121 /$ tader.680011.

ATIF: Karakuş, Abdulkadir. "Kur’an Meallerinde Bağlama Riayet Etmenin Önemi”. Tefsir Araşıtırmaları Dergisi (TADER) 4 / 1 (Mart 2020): 93-116. 


\section{4 | Karakuş, Kur’an Meallerinde Bağlama Riayet Etmenin Önemi}

\section{Giriş}

Kur'an'1 anlama ve yorumlama hususunda bağlamın belirlenmesi ve anlamın buna göre ortaya konulması çok önemlidir. Zira bağlama gerekli önemin verilmemesi sebebiyle çoğu zaman gerçek anlamdan uzaklaşıldığı bilinen bir gerçektir. Özellikle yirmi üç yıl gibi uzun bir sürede olayların akışına göre şekillenen vahyin inzal sürecindeki oluşumunu, bağlamından kopararak anlamaya çalışmak, zaman zaman eksik ve yanlış anlamalara sebep olabilmektedir. Dolayısıyla Allah'ın emir ve yasaklarını, kullarından isteklerinin neler olduğunu bilebilmek için, Kur'an'ın diliyle birlikte bağlamını da bilmek gerekmektedir. ${ }^{1}$ Nitekim günümüz meal yazarlarının en büyük eksikliklerinin başında ayetlere dair sahih "bağlam” bilgilerine sahip olmayışları gelmektedir.

Bağlamın önemini ortaya koyabilmek için önce bağlamdan ne kastedildiğini belirtmek gerekir. “Bu makalede üzerinde durduğumuz, ‘bağlam’ terimi iki şeye atıfta bulunmak için kullanılmıştır. Bunlardan ilki verilen bir kelime veya deyimden kastedilen ya da onun anlamını etkileyen ve Arapçada "سياق" (siyâk, bağlam) veya "سياق النص" (siyâku’n-nass, metnin bağlamı) olarak tabir edilen husustur. İkincisi ise, son zamanlarda yapılan çalısmalarda durum bağlamı diye ifade edilen, Kur'an'daki herhangi bir ifadeyi çevreleyen koşullar ya da olguları ifade eden husustur. Bu mesele Arap belâgatında “مقام" (makâm) diye bilinmekte ve "سياق الموقف" (siyâku'l-mevkerf, durum bağlamı) olarak adlandırilmaktadir."

Konuyu biraz açacak olursak siyâk sözlükte, "ساق - يسوق" (sâka - yesûkku) filininin bir mastar1 olup göndermek, sürmek, sevk etmek, salmak gibi anlamlara gelmektedir. Arapçada çarşıya es-sûk isminin verilmesi de, malların satılması için buraya sevk edilmesinden dolayıdır. ${ }^{4}$ Nasıl ki çarşıya mal getirmenin gayesi onları satmak ise, sözü sevk etmenin/söylemenin gayesi de onların anlamının ortaya çıkmasıdır. Bu yönüyle siyâk, sözün anlamının ortaya çıkması için gerekli olan şeylerdir.

Anlama ve yorumlama usulünün önemli bir konusunu ifade eden siyâk terimi ortam, bağlam, münasebet ve alâka demektir. ${ }^{5}$ Ayrıca "sözün gelişi, ifade tarzı, üslup, tarz, anlatım biçimi” manalarında kullanıldığ1 gibi, bir terkip olarak "سياق الكلام" (siyâku’l- kelâm) da "sözün gelişi”" anlamına gelmektedir. ${ }^{6}$

1 Yusuf Karadâvî, “Kur'ân Tefsirinde İdeal Yöntem”, trc. Muhittin Akgül, Diyânet İlmî Dergi 38/3 (2002): 68; Şahin Güven, Kur'ân'in Anlaşılması ve Yorumlanmasinda Cokanlamlılık Sorunu (İstanbul: Denge Yayınları, 2005), 240.

2 Giyasettin Arslan, “Türkçe Kur'ân-1 Kerîm Meallerinde Hedef Dilin Önemi”, Furat Üniversitesi İlahiyat Fakültesi Dergisi 8 (2003): 36.

3 Muhammad Abdel Haleem, “The Role of Context in Interpreting and Translating the Qur'an”, Journal of Qur'anic Studies 20/1 (2018): 47. https://doi.org/ 10.3366/jqs.2018.0320.

4 Ebü’l-Fadl Cemâlüddin İbn Manzûr, “Svk”, Lisânü'l-Arab, 3. Bask1 (Beyrut: Dâru Sâdır, 1414), 10: 166-167.

5 Mustafa Ünver, Kur'an’ı Anlamada Siyakın Rolü, Ankara: Sidre Yayınlar1, 1996),

6 Ali Bakkal, Kur'ân'ı Anlamada Siyak-Sibakın Önemi (İstanbul: İlim Yayma Vakfı Kur'an ve Tefsir Akademisi Yayınları, 2009), 12. 
Dilbilim açısından "bağlam", "bir ifade veya metinde belirli bir dilbilimsel birimi inceleyen ve takip eden seslerin, kelimelerin veya ibarelerin oluşturduğu bütün anlamına gelmektedir. Zira cümledeki bir kelime, o cümledeki diğer kelimelerle birlikte ve onlarla bütünleşerek, onların da yardımıyla bir anlam ifade eder. İsste kısaca kelimelerin bağlı bulunduğu bu unsurların oluşturduğu bütüne bağlam adı verilmektedir."

Makâm ise İnsanların sözleri, durumları ve sözlerini çevreleyen yeri veya şartları belirtmektedir. Makâm, hitabın ve muhatabın durumunu bilmek demektir. Temmâm Hassân'ın ${ }^{8}$ (ö. 2011) belirttiği gibi makâm: "Sözün söylendiği zamana hâkim olan ilişki, olay ve sosyal şartların ortaya çıkardığ1 durumdur."’ Yani makâm; söyleyenin, söze muhatap olanın ve dile getirilecek duygu, düşünce ve hayalin duruma uygun şekilde yerli yerinde söylenmesidir.

Bağlam sözün zincirleme olarak devam etmesi iken, makâm sözün icra edildiği ortamdır. Bir kitap, makale veya söylem orada geçen bir cümlenin bağlamını oluştururken; resmi bir ortam, kutlama, açilış, otobüste giden yolcunun durumu, o ortamlarda geçen diyaloglar açısından makamı oluşturur. "Ben sana cahillerden olmaman için öğüt veriyorum.” (Hûd 11/46) ayetinde her ne kadar literal/lafzi anlamdan "Ben sana cahillerden olmanı öğütlerim" şeklinde bir mana anlaşılabilir olsa da, metnin bağlamından bunun kastedilmediği açıkça fark edilir. ${ }^{11}$

Bağlam, tefsir ilminin de önemli konularından bir tanesidir. Nitekim âlimler, bağlama dikkat etmeden sadece lafzı anlamaya yoğunlaşarak yapılan tefsirleri yeterli bulmamışlar ve kabul etmemişlerdir. ${ }^{12}$ Bundan dolayı, Tefsir Usulü ilimlerinde bu konu müstakil olarak yer almasa da metin içi bağlamı ifade etmek için “ayetler ve sureler arası ilişkiler” (münâsebetu'l-ây ve's-suver) ifadesinin; metin dışı bağlamı ifade etmek için ise "nüzul sebepleri” (esbâbü’n-nüzûl) ifadesinin kullanıldığını söylemek mümkündür. ${ }^{13}$ Ancak terim olarak siyak sözcüğü Kur'an’da “sözün sevk edilişi” anlamında kullanılmadığı gibi nüzul sonrasında da bu anlamda kullanılmamıştır. Terim anlamıyla siyak kelimesi ilk olarak İmam Şafiî (ö. 204/820) tarafindan er-Risâle isimli eserinde kullanılmıştır. ${ }^{14}$

\footnotetext{
Doğan Aksan, Her Yönüyle Dil (Ankara: TDK Yayınları, 1995), 3: 524.

8 Arap dünyasında modern dil araştırmalarının öncülerindendir. Hakkında fazla bilgi edinmek için bkz. Türkiye Diyanet Vakfi. “Temmam Hassan”. Erişim: 5 Temmuz 2018. https:/ /islamansiklopedisi.org.tr/temmam-hassan.

9 Temmâm Hassan Ömer, el-Lüğatu'l Arabiyye Ma'nâhâ ve Mebnâhâ, 5. Baskı (Beyrut: Âlemü’l Kütüb, 1427/2006), 337.

10 İlyas Karslı - Ahmet Kaplan, "Dilde Anlam ve Karine İlişkisi”, Recep Tayyip Erdoğan Üniversitesi Illabiyat Fakïltesi Dergisi 10 (2016): 16.

11 Yaşar Daşkıran, “Temmâm Ḥassân’ın Dil Anlayışı: Karineler Teorisi”, Ankara Üniversitesi İlabiyat Fakültesi Dergisi 56/2 (2015): 150

12 Bk. Takiyyuddin İbn Teymiyye, Mukaddime fì Usuli't Tefsir (Beyrut: Dâru mektebeti'l-hayât, 1490/1980), 33.

13 Güven, Kur'an'mn Anlaşlmasi, 247.

14 Kavramın kullanımının kısa tarihçesi ile ilgili olarak bk. Avnullah Enes Ateş, Kur'an Yorumunda Siyakın Yeri -Zemabșeri Özelinde- (İstanbul: Kitâbî Yayınları, 2018), 22-27.
} 
Şimdiye kadar "Kur’an ve Bağlam” temalı oldukça fazla araştırma yazısı yayınlanmış ve bağlamın önemine, daha çok teorik olarak vurgu yapılmıştır. ${ }^{15}$ Ancak bu makaleyi diğerlerinden ayıran özellik, bağlamın önemini teorik olarak anlatmaktan ziyade, meallerde bağlama ne oranda riayet edildiğini ortaya koymak; bağlama riayet etmenin anlam üzerindeki etkilerini, anlama yaptığı katk1ları ve kazandıracağı zenginlikleri örnekler üzerinden göstermeye çalışmaktır. Bu konuda M. A. Abdel Haleem’in kaleme aldığı bir araştırmada, ${ }^{16}$ batı dillerine çevrilen Kur'an meallerine göre birkaç ayetin bağlam açısından incelenmesi, bu makaleye de ilham kaynağı olmuş ve makalenin oluşmasına zemin hazırlamıştır. Abdel Haleem bu makalesinde pek çok konuya temas ederken birkaç ayeti de meallerle karşılaştırarak vermiş ve bağlam anlam ilişkisine dikkat çekmiştir. Bu makalede ise konu tamamen muhtelif ayetlerin meallerle karşılaştırılarak, bağlam anlam ilişkisini belirlemeye yönelik olarak belirlenmiştir.

Ele alınan mealler ise, tarafımızca insanların çokça müracaat ettiği düşünülen meallerden seçilmiştir. ${ }^{17}$ Diyanet İşleri Başkanlığının ve onun bir yan kuruluşu olan Diyanet Vakfının kurumsal kimliğinin, hazırladıkları meallerin halk arasında çokça rağbet göreceği fikrinden yola çıkılarak bu kanaate varılmıştır. Muhammed Esed meali ise son dönemlerde pek çok meale kaynaklık ettiği göz önüne alınarak seçilmiştir.

\section{Bağlam Anlam İlişkisi Çerçevesinde Bazı Ayetlerin Mukayeseli Olarak İncelen- mesi}

\section{1. İsrâ Suresi 94. Ayet}

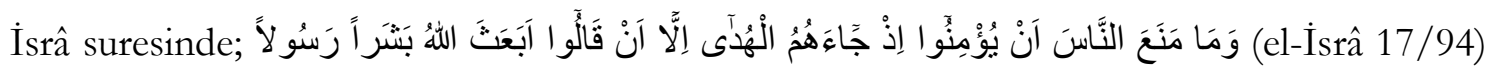
buyrulmuştur. Ayetin anlamı Kur'an meallerinde şu şekilde verilmiştir:

"Kendilerine kurtuluş rehberi (vahiy) geldiğinde insanların inanmalarını, ancak 'Allah, peygamber olarak bir beşeri mi gönderdi?’ şeklindeki itirazları engellemiştir.” (Kur'an Yolu Meal ve Tefsir)

\footnotetext{
15 Bu makalelerin bir kısmından faydalanarak dipnotlarda gösterdik. Diğer birkaç tanesi için bk. Necmettin Gökkır, “Tefsir Usulünde "Lafız-Mana" ilişkisinin Tespiti ve Bağlam Bilgisinin Önemi”, Kur'an İlimleri ve Tefsir Usulü (Ağustos 2009): 333-344; Nihat Uzun, "Bağlamı Göz Ard1 Etmek: Siyâsî Mücadelelerde Âyetlerin Kullanımı", Atatük Üniversitesi İlabiyat Fakültesi Dergisi 37 (2012): 1-28; Mustafa Ünver, "Tefsirin Temel Bir İlkesi Olarak Siyaka Riayet -Elmalılı Tefsiri Örneği-”, Tefsir Arasstırmalar Dergisi 1 (Nisan 2017): 73-120; Fatih Tiyek, Kur'an'ı Anlamada Bağlamın Rolï ve Meallerdeki Bağlamsal Sorunlar (Ankara: Ankara Okulu Yayınları, 2015).

16 Abdel Haleem, "The Role of Context", 47-66.

17 Bu meallerden ilki, Diyanet İşleri Başkanlığınca yayınlanan Kur’an Yolu Meal ve Tefsir isimli eserdeki meal, ikincisi bizzat Diyanet İşleri Başkanlığınca en son yayınlanan meal ve sonuncusu ise Muhammed Esed'in mealidir. Bu meallerin seçilmesi, çok fazla müracaat edilen mealler olması sebebiyledir. Bu üç mealden başka bir meal incelemeye tabi tutulmamıştır.
} 
"İnsanlara hidayet (Kur'an) geldikten sonra onların iman etmelerine ancak, 'Allah bir beşeri mi peygamber olarak gönderdi?’ demeleri engel olmuştur.” (Halil Altuntaş - Muzaffer Şahin, Kur'an$\imath$ Kerîm Meâli [DİB Meali])

“(Işste bunun gibi,) insanlara (bir peygamber eliyle) doğru yol bilgisi geldiği zaman onları (ona) inanmaktan alıkoyan, onların: ‘Allah ölümlü bir insanı mı elçi olarak gönderdi?’ diye itiraz etmelerinden başka bir şey değildir.” (Muhammed Esed, Kur'an Mesaji)

Meallerde "النَّاس”" (insanlar) kelimesi genel anlamda insan cinsine yapilan bir hitap olarak ele alınmış ve bu şekilde mana verilmiştir. Bazı kaynaklarda, Kur’an’ın hitap kalıpları içerisinde "'النَّاس" kelimesinin genel manada insan cinsini kastettiği belirtilmiş olsa da ${ }^{18}$ ayette bahsedilen "النَّاس" (insanlar)ın kimler olduğu konusu sadece bu ayete bakarak anlaşlabilecek bir konu değildir. Bu ayetin muhataplarını anlamak için bağlamı tespit etmek gerekmektedir.

Bu ayetin öncesindeki ayetlerde şöyle buyrulmaktadır: "Dediler ki: 'Yerden bize bir pınar fişkırtmadıkça yahut senin hurmalardan, üzümlerden oluşan bir bahçen olup, aralarından şırıl şırıl 1rmaklar akıtmadıkça yahut iddia ettiğin gibi, gökyüzünü üzerimize parça parça düşürmedikçe yahut Allah'ı ve melekleri karşımıza getirmedikçe yahut altından bir evin olmadıkça, ya da göğe çıkmadıkça sana asla inanmayacağız. Bize gökten okuyacağımız bir kitap indirmedikçe göğe çıktığına da inanacak değiliz.' Onlara: 'Rabbimi tenzih ederim. Ben ancak resul olarak gönderilen bir beşerim.' de.” (el-İsrâ 17/90-93).

Konumuz olan ayeti bu ayetlerle birlikte okuduğumuz zaman ayetin bağlamını daha kolay tespit edebiliriz. İlk ayetin “" kelimesinin başında belirlilik edat1 olan "harfi tarif" vardır. Bu harf, ya cinsiyyedir ve tüm insan cinsini içine alır ya da ahdiyyedir ve bilinen bir insan grubunu kapsar. ${ }^{19}$ Ayetteki “"النَّاس" kelimesinin başındaki harfi tarifin tüm insanları

18 Celâlüddin es-Suyûtî, el-İtkân fî ulûmi'l-Kur'ân (Beyrut: Dâru'l-ma'rife, ts.), 2: 43; İsmail Cerrahoğlu, Tefsir Usûlü (Ankara: TDV Yayınları, 1988), 2: 43. Bunun yanında tefsir kitaplarında ilk dönemlerden itibaren ayetteki " النَّاس" kelimesine, "kavmini iman etmekten alıkoyan Mekkeli müşrikler” şeklinde anlam verenler de olmuştur. Bk. Ebü’lHasen Mukâtil b. Süleymân b. Beşîr el-Ezdî, Tefsîru Mukâtil b. Süleymân, thk. Abdullah Mahmûd Şehhâte (Beyrut: Dâru İhyâi't-türâs, 1423), 2: 550; Muhammed b. Cerîr et-Taberî, Camiu'l-beyân fì te'vîli'l-Kur'ân, thk. Ahmed Muhammed Şâkir (b.y.: Müessesetü'r-risâle, 1420/2000), 17: 558.

19 Cinsiyye: "Bu türden olan lâm-1 tarif, ahd ifade etmeyip cins ifade eder. Burada başına ال gelmiş olan isim mana yönüyle nekreliğini devam ettirirken lafız yönüyle marife olmaktadır." Ahdiyye: "Nekre bir kelimenin başına gelerek, daha önce manası kapalı ve umum durumda olan nekrenin medlûlünü belirli bir ferde hasredip, k1sıtlayarak ona belirlilik sağlar. Bu çeşit ال eklendiği kelimeyi muhatap tarafindan bilinen, belirli bir fert haline getirmektedir.” Ayrıca harfi tarif, eklendiği bazı kelimelerde ism-i mevsûl, ivaz (karşılık) ve zâid olarak da bulunmaktadır. Bu konuda fazla bilgi için bk. Ebû Muhammed Abdullâh Cemâleddîn b. Yûsuf b. Ahmedb. Hişâm, Muggni'l-lebîb 'an kutubi'l-eârî̉, thk. Mâzin el-Mübârek - M. Ali Hamdullah, 6. Baskı (Dımeşk: Dâru'l-fikr, 1985), 72; Tahsin Deliçay - Sadık Koç, “Arap Dilinde Harf-i Ta'rif", Furat Üniversitesi Sosyal Bilimler Dergisi 12/2 (2002): 196-199; Nejdet Gürkan, "Arapçada "El”" Takısı ve Fonksiyonları”, Ekev Akademi Dergisi 18 (2004): 357-374; Yılmaz Bidav, Arap Dilinde Zâid Harfler (Yüksek Lisans Tezi, Selçuk Üniversitesi, 2015), 83-84. 
kapsadığını varsaydığımızda bunun mümkün olmadığı görülecektir. Çünkü biz biliyoruz ki (geçmişte) birçok topluma insan peygamberler gönderilmiştir ve bütün bir insanlığın "insan peygamber" fikrini tuhaf bulduğu veya bu durumu, inanmamak için bir gerekçe olarak ileri sürdüğü söylenemez. ${ }^{20}$

Ayrıca daha sonra gelen ayette özellikle Hz. Peygamber'e hitaben “onlara de ki” şeklinde bir hitapla, muhatap olduğu Mekkelilerin melek olmadığı, bundan dolayı da peygamber olarak kendilerine melek gönderilmediği ifade edilmektedir. ${ }^{21}$

Ayetin bağlamını biraz daha genişleterek: "Ĕ̆ger doğru söyleyenlerden isen bize melekleri getirsene!" (el-Hicr 15/7) ve "Dediler ki: Bu ne biçim peygamber ki yemek yer, çarşıda, pazarda dolaşır. Ona bir melek indirilseydi de bu onunla beraber bir uyarıcı olsaydı ya!’ (el-Furkân 25/7) ayetlerini de bağlamın kapsamına kattığımızda, bu ayetin anlamı daha net bir şekilde ortaya çıkacaktır. Böylece ayetin, tüm insanlığa değil de bu sözleri söyleyen ve ayette de söz konusu edilen "Mekkeli insanlar"a hitap ettiği daha açık bir şekilde anlaşılacak ve böylece bağlamın belirlenmesiyle daha zengin anlamlara ulaşmak mümkün olacaktır. Bu durumda ayeti; "Mekke müşriklerine hidayet (Kur'an) geldikten sonra onların iman etmelerine ancak, 'Allah bir beşeri mi peygamber olarak gönderdi?’ demeleri engel olmuştur.” şeklinde de anlamlandırabilme imkânı olduğu ortaya çıkacaktır.

O zaman bu kelimenin başındaki harfi tarifin cinsiyye olmadığı ve belirli bir insan grubunu kapsadığı, bu insan grubunun da önceki ayetlerde belirtildiği gibi peygamberden pek çok isteklerde bulunan kişiler olan Mekkeli müşrikler olduğu belirgin hale gelecektir. ${ }^{22}$

\subsection{Meryem Suresi 71. Ayet}

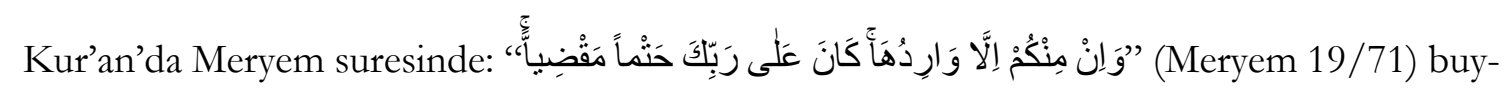
rulmuştur. Bu ayetin meallerine baktığımızda şu anlamlar karşımıza çıkar:

"İçinizden, oraya varmayacak hiçbir kimse yoktur. Bu, Rabbinin kesinleşmiş bir hükmüdür." (Kur'an Yolu Meali)

“(Ey insanlar!) Sizden cehenneme varmayacak hiç kimse yoktur. Rabbin için bu, kesin olarak hükme bağlanmış bir iştir.” (DİB Meali)

"Ve sizin her biriniz onu görebilecek bir noktaya varacaksınız: Bu, Rabbin katında yerine getirilmesi gerekli bir hükümdür.” (Muhammed Esed Meali)

20 Abdel Haleem, "The Role of Context", 52.

Bk. el-İsrâ $17 / 95$.

22 Aynı anlamı ortaya koyan tefsir kaynakları için bk. Mukâtil b. Süleymân, Tefsîru Mukâtil, 2: 550; Taberî, Camiu'lbeyân, 17: 558; Ebü’l-Berekât Abdullah b. Ahmed b. Mahmûd Hâfizüddin en-Nesefî, Tefsîru'n-Nesefì (Medârikë̈ttenzîl ve hakâiku't-te'vîl), thk. Yûsuf Ali Bedîvî (Beyrut: Dâru'l-kalem et-tayyib, 1419/1998), 2: 278. Abdel Haleem, “The Role of Context”, 52'de aynı ayeti ele almış ve bu kanaati ortaya koymuştur. 
Bu ayete ilk iki mealde bütün insanların cehenneme uğrayacağı, son mealde ise bütün insanların cehennemi görecek bir yere kadar geleceği şeklinde anlam verilmiştir. Burada asıl mesele ayet-

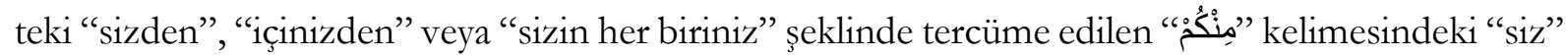
zamirinden kimlerin kastedildiğini tespit etmektir. Her üç mealde de bu zamirden kastedilen ismin tüm insanlar olduğu belirtilmiştir. Ayetle ilgili tefsirlerimize baktığımız zaman da, ayetten iyi veya kötü tüm insanların cehenneme girecekleri şeklinde bir anlamın çıkarıldığ1 ve zamire bütün insanlar anlamı verildiği görülür. ${ }^{23}$

Bu kelimedeki “" "siz" " zamirinden kimlerin kastedildiğini anlamak için bağlama, dolayısıyla önceki ayetlere bakmak gerekmektedir. Çünkü zamir daha önce zikredilmiş bir ismin yerine gelmektedir.

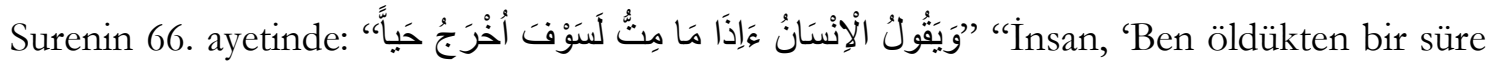
sonra sahiden yeniden hayata döndürülecek miyim?’ diyor.” (Meryem 19/66) buyrularak dirilmeyi inkâr eden bir insandan bahsedilmekte ve o insanla ilgili olarak “ "لإْنْسَانُ" tabiri kullanılmakta ve bu kelime "cinsiyye" olarak kabul edilerek, yukarıda kaynakları verilen tefsirlerde tüm insan cinsini içine aldığı var sayılmaktadır. Hâlbuki ayet bağlama dikkat ederek okunduğunda, buradaki "el-insan” tabirinden dirilmeyi inkâr eden kişilerin kastedildiğinin anlaşılması zor olmayacaktır.

Ayetin devamında da aynı kişilerle alakalı şunlar söylenmektedir: "(Dirilmeyi inkâr eden bu) insan, daha önce hiçbir şey değil iken kendisini yarattığımızı düşünmez mi?” (Meryem 19/67). "Rabbine andolsun ki onları muhakkak şeytanlarla birlikte mahşerde toplayacağız; sonra onları cehennemin çevresinde diz üstü çökmüş vaziyette hazır tutacağız.” (Meryem 19/68). "Sonra her gruptan, Rahmân'a en çok âsi olanlar hangileri ise çekip çıaracağız.” (Meryem 19/69). "Sonra, cehenneme girmeye en layık olanları muhakkak ki en iyi biz biliriz.” (Meryem 19/70).

Bu ayetler düz bir okumaya tabi tutulduğunda görülür ki burada yeniden dirilmeyi inkâr eden bazı insanlardan bahsedilir ve onlara, "siz hiç yokken sizi yaratan Allah, sizi, öldükten sonra da yeniden var edecektir.” şeklinde hitap edilerek yeniden dirilmenin mümkün olduğu ortaya konmakta ve yeniden dirilişi inkâr edenlerin cehennemde diz çöktürülecekleri beyan edilmektedir. $\mathrm{Bu}$ bilgiler üzerine ilk başta sözünü ettiğimiz 71'inci ayet okunacak olursa görülecektir ki ayette söz

23 Bk. Taberî, Camiu'l-beyân, 18: 230; Ebû Mansûr el-Mâtürîdî, Tefsîru'l-Mâturî̀t̂̀ - Te'vîlâtü ebli's-sünne, thk. Mecdî Bâsellûm (Beyrut: Dâru'l-Kütübi'l-İlmiyye, 1426/2005), 7: 252; Ebü'l-Kâsım Mahmûd b. Amr b. Ahmed ez-Zemahşerî, el-Keş̧ấf an bakâiki gavâmizi't-tenzîl, 3. Bask1 (Beyrut: Dâru'l-kitâbi'l-Arabî, 1407), 3: 34; Fahruddin er-Râzî, Mefâtîhu'l-gayb - Tefsiru'l-kebîr, 3. Bask1 (Beyrut: Dâru ihyâi't-türâsi'l-Arabî, 1420), 21: 557; Ebû Abdillah Şemsüddin el-Kurtubî, el-Câmin li abkâmi'l-Kur'ân, thk. Ahmed el-Berdûnî - İbrahim Etfîş, 3. Baskı (Kahire: Dâru'l-kütübi'lMisriyye, 1384/1964), 11: 136; Süleyman Ateş, Kur'ân-ı Kerîm Tefsiri (İstanbul: Yeni Ufuklar Neşriyat, 1988), $3: 1625$. Hayreddin Karaman v.dğr., Kur'an Yolu Türkşe Meal ve Tefsir (Ankara: DİB Yayınları, 2007), 3: 613'de her insanın potansiyel olarak ameline göre cennete olduğu gibi cehenneme de gidebileceği ifade edilerek zamire bütün insanlar anlamı verilir. 
konusu edilen kişiler yeniden dirilişi inkâr eden insanlardır. Bu durumda ayetin mealinin; "İşte bu gruptan olan insanlardan cehenneme uğramayacak hiç kimse yoktur. Rabbin için bu, kesin olarak hükme bağlanmış bir iştir.” şeklinde olduğu görülecektir. ${ }^{24}$ Ayetteki “"الْلْنْسَانُ kelimesinin tüm insanlar olarak yorumlanmasından dolayı üçüncü mealde, "insanların cehennemi görecek bir noktaya gelecekleri” gibi bir yorumlamaya gidilmiştir. Zaten daha sonra gelen ayette de; "Sonra Allah'a karş1 gelmekten sakınanları (cehennemden) esirgeriz de zalimleri orada diz üstü çökmüş halde bırakırız." (Meryem 19/72) buyrularak Rablerine karşı gelmekten sakınanların cehenneme hiç girmeyeceği açık ifadelerle vurgulanmaktadır. Ĕğer ayetin bu şekilde anlaşılmasına, "herkes cehenneme girecek ve iyiler tekrar çıkarılacaktır” şeklinde yorumlanabileceği noktasında bir itiraz gelecek olursa bu da, “Tarafımızdan kendilerine güzel akıbet takdir edilmiş olanlara gelince, işte bunlar cehennemden uzak tutulurlar.” (el-Enbiyâ 21/101) ayetine ters düşecektir.

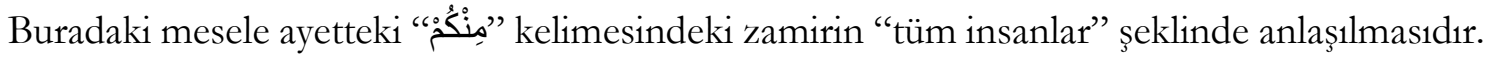
Eğer bu kelimedeki zamir bağlama uygun olarak, "dirilişi inkâr eden insanlar" şeklinde anlaşılsa ayetin anlamı yerli yerine oturacaktır.

\subsection{Müddessir Suresi 6. Ayet}

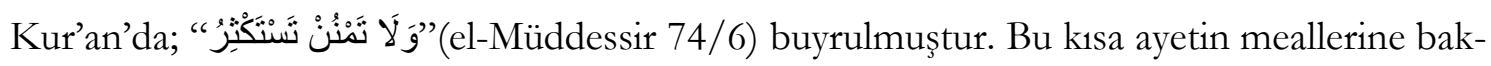
tığımız zaman şu şekilde anlamlarla karşılaşırız:

"Yaptığın iyiliği çok görerek başa kakma.” (Kur’an Yolu Meali)

"İyiliği, daha fazlasını bekleyerek (bir kazanç elde etmek için) yapma.” (DİB Meali)

“İyilik yapmayı kendine kazanç aracı kılma” (Muhammed Esed Meali)

Ayetteki ““نْنَ fiili burada her üç mealde de “iyilik yapmak” olarak anlaşılmış ve o şekilde tercüme edilmiştir. Aslında ayeti okuduğumuzda akla gelen ilk anlam budur. Fakat ayet bağlamı içerisinde değerlendirildiği zaman karşımıza daha başka bir anlam da çıkar. Bu sure Hz. Peygamber'e hitaben, peygamberlik görevinin verildiği ilk günlerde Müzzemmil suresinden sonra nazil olmuştur $^{25}$ ve ilk ayetleri: "Ey örtünüp bürünen (Peygamber!) Kalk da uyar. Rabbini yücelt. Nefsini arındır. Şirkten uzak dur.” (el-Müddessir 74/1-5) şeklindedir. Ayetin devamında, Hz. Peygamber'den, konunun başında örnek olarak ele aldığımız meallerde de vurgulandığı gibi iyilik yapması

24 Bk. Râzî, Mefâtîhu'l-gayb, 21: 557.

25 Bk. Zemahşerî, el-Kesşâf, 4: 644; Karaman v.dğr., Kur'an Yolu, 5: 491; Mustafa İslamoğlu, Kur'an Sûrelerinin Kimliği, 11. Baskı (İstanbul: Akabe Vakfı Yayınları, 2011), 439; M. Kâmil Yaşaroğlu, "Müddessir Sûresi”, Türkiye Diyanet Vakfi İslâm Ansiklopedisi (İstanbul: TDV Yayınları, 2006), 31: 463-464. Ayrıca bu sürenini ilk nazil olan sure olduğunu belirten rivayetler de vardır. Bk. Müslim, "İman”, 73; Râzî, Mefâtîhu'l-gayb, 30: 696. 
yani vermesi emredilmektedir. Ancak, ayetin nazil olduğu dönemde, Hz. Peygamber’in başkalarına iyilik yapmak üzere vereceği maddi imkânı yoktur. ${ }^{26}$

Bu ayeti, Müddessir suresi ile aynı dönemde nazil olan Müzzemmil suresinde ${ }^{27}$ Allah'1n Hz. Peygamber'e hitaben: “Geceleyin -birazı dışında- namaza kalk!” (el-Müzzemmil 73/2) şeklindeki emri ve: “Şüphesiz biz sana (sorumluluğu) ağır bir söz vahyedeceğiz.” (el-Müzzemmil 73/5) ayetiyle beraber değerlendirdiğimiz zaman, görürüz ki, Hz. Peygamber, uhdesine tevdi edilen yükün ağırlığılla bunalmıştır. Buradaki ağıllı̆̆ı, vahiyle gelen emirlerin gereğiyle amel etmenin ağırlı̆̆1 ve vahyin yüklediği sorumluluk ${ }^{28}$ olarak algılamalıdır; yoksa vahyin gelmesinin peygambere eziyet veren bir

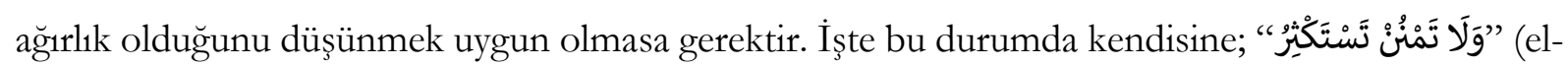
Müddessir 74/6) denilerek, "Bunları büyük bir külfet görerek gevşeklik gösterme” mesajı ulaştırılmıştır. ${ }^{29}$ Bu anlam, bağlamsal olarak, bu ayetin hemen peşinden gelen, “Rabbinin rızasına ermek için sabret.” (el-Müddessir 74/7) ayetiyle de desteklenmiştir. Söz konusu ayet lügat yönünden incelendiğinde de: "Bunları çok görerek gevşeklik gösterme” manasının ortaya çıkma-

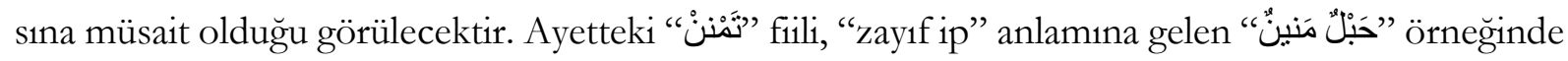
de görüleceği gibi “zayıf düşme, gevşeklik gösterme” manasına gelmektedir. Hz. Peygamber de vahyin yüklediği sorumluluk sebebiyle zayıf düşmüş ve zorlanmıştır. Bundan dolay1 (el-Müddessir 74/6) ayetindeki “نْنَنَن kelimesini, bağlamdan dolay1 “zayıflık göstermek” şeklinde anlayanlar olmuştur. ${ }^{30}$

Hâsılı bu ayet, Kur'an ayetlerinin bağlamında değerlendirilmesiyle nasıl daha farklı ve zengin anlamlar içeren sonuçlara ulaşılacağının önemli bir örneğini oluşturmaktadır.

26 Hz. Peygamber’in maddi durumu kendine yetecek düzeydedir. Varlıklı bir aileden olmadığı gibi zenginlikte de hiç gözü olmamıştır. "Nübüvvetinin Mekke döneminde mal varlığında artıştan ziyade azalmalar olduğu hatta kimi zaman bu mal varlığının tamamen tükendiği söylenebilir. Özellikle bi’setin yedinci yılında Mekke müşrikleri tarafindan uygulanan ambargo esnasında diğer Müslümanlar gibi Peygamberimiz ve ailesinin de çok sıkıntılara düştükleri, hatta günlerce aç kaldıkları kaynaklarımızda nakledilmektedir.” Bk. Ünal Kılıç, "Peygamberimizin Risalet Öncesi Geçim Durumu", İstem 4 (2004): 189-200. Ayrıca bk. İmamı Tirmizî, Şemâil-i Şerîf Tercemesi, trc. Muhammed Raif Efendi, sad. Bekir Başarıcı (Konya: İhya Yayınları, ts.), 312-323.

27 Müddessir suresi ile Müzzemmil suresinin aynı dönemlerde indiği ile ilgili olarak bk. Ebü’l-Kâsım Mahmûd b. Amr b. Ahmed ez-Zemahşerî, el-Keşşâf an hakâiki gavâmiz̧i't-teñîll, 3. Bask1 (Beyrut: Dâru'l-kitâbi'l-Arabî, 1407), 4: 644; Karaman v.dğr., Kur’an Yolu, 5: 482; İslamoğlu, Kur'an Sûrelerinin Kimliği, 436; M Kâmil Yaşaroğlu, "Müzzemmil Sûresi”, Türkiye Diyanet Vakfi İslâm Ansiklopedisi (İstanbul: TDV Yayınlar1, 2006), 32: 252.

28 Bk. Taberî, Camiu'l-beyân, 23: 681; Zemahşerî, el-Keş̧âf, 4: 637-638; Râzî, Mefâtîhu’l-gayb, 30: 683.

29 Karaman v.dğr., Kur'an Yolu, 5: 495'te bu ayetin anlamlarından birinin de "Ey Peygamber! Sakın şerefli ve değerli peygamberlik vazifesinin külfet ve meşakkatini çok görme, bunlara gönül rızası ile katlan” şeklinde olduğuna dikkat çekilmiştir.

30 Bk. İbn Manzur, “Mnn”, Lisânü'l-Arab, 13: 415; Râzî, Mefâtîhu'l-gayb, 30: 700. Ayrıca bu ayeti ele alan Abdel Haleem de aynı sonucu ortaya koymuştur. Bk. Abdel Haleem, "The Role of Context", 51-52. 


\subsection{Kıyâme Suresi 16-19 ve 31-32. Ayetler}

\subsubsection{Kıyâme 16-19}

Kıyâme suresinde söze yeminle başlanmıştır. Kıyamet hadisesinin mutlaka gerçekleşeceği bildirilmiş, o esnada meydana gelecek olan bir takım olaylardan bahsedilmiş ve sonrasında da: "O gün varıp durulacak yer, sadece Rabbinin huzurudur.” (el-Kıyâme 75/12). “O gün insana, yapıp önden gönderdiği ve yapmayıp geri bıraktığı şeyler haber verilir." (el-Kıyâme 75/13). "Hatta mazeretlerini ortaya koysa da, o gün insan kendi aleyhine şahittir. (el-Kıyâme 75/14-15) buyrulduktan sonra sure

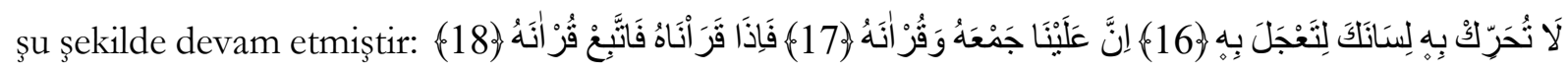
(19) نُمَّ إنَّ عَلَيْنَا بَيَانَنُ (el-Klyâme 75/16-19).

Bu ayetler Kur'an meallerinde şu şekilde ifade edilmiştir:

"Vahyi tam alma telâşı yüzünden dilini kımıldatma. Onu zihninde toplayıp okumanı sağlama işi bize aittir. O halde onu okuduğumuz zaman sen onun okunuşunu takip et. Sonra onu anlatmak elbette bize aittir.” (Kur'an Yolu Meali)

“(Ey Muhammed!) Onu (vahyi) çarçabuk almak için dilini kımıldatma. Şüphesiz onu toplamak ve okumak bize aittir. O halde, biz onu okuduğumuz zaman, onun okunuşuna uy. Sonra onu anlatmak elbette bize aittir.” (DİB Meali)

“(Vahyin sözlerini tekrarlarken) dilini hızla oynatıp durma; çünkü onu (senin kalbine) yerleştirmek ve (gerektiğinde) okutturmak Bizim işimizdir. Böylece, onu telaffuz ettiğimiz zaman, kelimelerini (bütün zihnini vererek) takip et, sonra onun anlamını açılamak da Bize düşer." (Muhammed Esed Meali)

Yirminci ayetten itibaren ise ayetler yine kıyamet halleri ile ilgili konulara geri döner ve: "Hayır! Siz dünyayı seviyorsunuz ve ahireti bırakıyorsunuz. O gün bir takım yüzler aydındır.” (elKıyâme 75/20-21) buyrulur.

Buraya kadar verdiğimiz ayetleri üç grup olarak tanımlamak mümkündür. İlk grup 12-15’inci ayetler, ikinci grup 16-19'uncu ayetler ve son grup ise 20-21'inci ayetlerdir. Bu ayetler grubunu aynı bağlamda düşündüğümüzde, ikinci grup, bağlamın ifade ettiği anlamdan kopmakta ve farklı bir konudan bahsetmektedir.

Hâlbuki Tefsir Usulü kitaplarımızda Münasebetü'l-Kur'an konusu anlatıllırken hem ayetler hem de sureler arasında, sanki tamamı bir kelime imiş gibi mantıksal bir anlam ilişkisinden bahsedilir. Sadece birbirini takip eden ayet ve sureler değil, tüm ayet ve surelerin uyumundan; yine, surelerin başlarıyla sonları, bir surenin sonuyla diğer surenin başı arasında dahi anlam bakımından makul ve mantıklı bir uyumdan; hatta Kur'an'ın ilk suresi ile son suresinin arasındaki mana ilişkisinden söz 
edilir. Bu söylenenlere de pek çok misaller verilir. Mesela Fâtiha suresinin başında, hamdin Allah'a mahsus olduğu vurgulanırken, surenin sonunda ise hidayeti ancak hamd edilmeye layık bir varllğın verebileceği belirtilerek hidayetin sadece ondan isteneceği dile getirilir. Bakara suresinin hemen başında da müminlere istedikleri hidayetin ellerindeki Kur'an olduğu haber verilir. ${ }^{31}$

Fahreddin er-Râzî (ö. 606/1210) Bakara suresinin başıyla sonu arasındaki münasebeti şöyle ifade etmiştir: “Allah Bakara suresinin başında gayba iman eden, namaz kılan ve Allah'1n kendilerine verdiği rızıktan infak edenleri övmüş; surenin sonunda da bunların Hz. Muhammed'in ümmeti olduğunu belirtmiştir. Ayrıca surenin başında gayba imandan söz edip; sonunda da bunun Allah'a, meleklere, kitaplara ve peygamberlere iman olduğunu vurgulamıştır.”32

Mesela Vâkıa suresinin sonuyla Hadîd suresinin başı arasında akli ve mantıki bir uyum vardır. Zira Vâkıa suresi: “Öyleyse Ulu Rabbinin adını tesbih et.” (el-Vâkı 56/96) ayetiyle sona ererken Hadîd suresi ise "Göklerde ve yerde ne varsa Allah'1 tesbih etmektedir." (el-Hadîd 57/1) ayetiyle başlamaktadır ve ayet ve sureler arası uyum ile alakalı olarak daha pek çok örnek vermek mümkündür. Ancak bu kadarı bile bizim ayetler arası münasebeti anlamamıza yeterlidir.

Kur'an ayetleri arasında böylesine ince, anlamlı ve mantıklı bir uyum mevcut iken, Kıyâme suresinin söz konusu ayetleri arasında ortaya çıkan bu durumu nasıl ifade etmek gerektiği önemli bir soru olarak karşımızda durmaktadır. Bu ayetlere, yukarıda işaret ettiğimiz şekilde anlam verilmesinden dolayı ortaya çıkan uyumsuzluğa dikkat çekmek üzere bazılarının; "bu sureden bir şeyler eksiltilmiştir" dedikleri kaynaklarımızda mevcuttur. ${ }^{33}$ Eğer ayet bağlamından bağımsız olarak anlamlandırılacak olursa, bu tür uyum problemleriyle karşılaşmak kaçınılmaz olacaktır.

Konunun başında ikinci grup olarak verdiğimiz ayetlerde, buradaki hitabın Hz. Peygamber'e olduğu düşünülerek ayetler bu kabule göre anlaşılmaya çalışılmıştır. Kur'an'da aynı anlama gelen başka ayetlerin de olması, ${ }^{34}$ muhtemelen bu ayetlerin, farklı bağlamlarda başka anlamlar da ifade edebileceğini düşünmeye mani olmuştur. Fakat bağlama baktığımızda bu ayetlerdeki hitabın $\mathrm{Hz}$. Peygamber'e olması daha uzak bir ihtimaldir. Çünkü buradaki muhatap: “O gün insana, yapıp önden gönderdiği ve yapmayıp geri bıraktığ1 şeyler haber verilir.” (el-Kıyâme 75/13) ayetinde söz konusu edilen insandır. Zira insan o gün amel defterini eline almış ve: "Şimdi kitabını oku bakalım. Bu gün kendi hesabını yine kendin göreceksin.” (el-İsrâ 17/14) ayetinde bildirildiği veçhile amel

31 Bedruddin ez-Zerkeșî, el-Burbân fî ulumi'l-Kur'ân (Beyrut: Dâru'l-ma'rife, 1376/1957), 1: 38; Suyûtî, el-Ittkân fî ulumi'lKur'ân, 2: 142; Muhsin Demirci, Tefsir Usûlü, 41. Baskı (İstanbul: M. Ü. İlahiyat Fakültesi Vakfı Yayınları, 2015), 202.

32 Râzî, Mefâtîhu'l-gayb, 7: 106.

33 Bk. Suyûtî, İtkân, 2: 141; Râzî, Mefâtîhu'l-gayb, 30: 726.

34 "Gerçek hükümdar olan Allah yücedir. Sana vahyedilmesi tamamlanmadan önce Kur'an'ı okumakta acele etme. 'Rabbim! İlmimi arttır’ de.” (Tâhâ 20/114). 
defteriyle yüzleşmektedir. Bu yüzleşme sonucunda o insan: "Kitap ortaya konur. Suçluları, kitabın içindekilerden korkuya kapılmış görürsün. 'Eyvah bize! Bu nasıl bir kitaptır ki küçük, büyük hiçbir şey bırakmadan hepsini sayıp dökmüş!' derler. Onlar bütün yaptıklarını karşılarında bulurlar. Senin Rabbin hiç kimseye zulmetmez." (el-Kehf 18/49) ayetinde de belirtildiği gibi dünyada yaptığı her şeyin kayıt altına alındığını görecektir. İşte amel defterinde gördüğü kötü amellerin verdiği korku ve heyecanla dili dolaşacak, bunun üzerine kendisine denilecek ki: "Telaşla dilini dolaştırıp durma." (el-Kıyâme 75/16). "Bütün yaptıklarını bir araya toplayıp onları sana okumak bizim işimizdir.” (elKıyâme 75/17). "Biz sana o kitaptan ne okumuşsak onları itiraf et.” (el-Kıyâme 75/18). "Sonra o kitapta olan şeyleri sana tek tek açıklamak bize aittir." (el-Kıyâme 75/19). ${ }^{35}$

Bağlama dikkat ederek ayetlere yaklaşma sonucunda elde edilen bu sonuç, Kur'an'in anlam zenginliklerini günümüze yansıtmaya ve farklı anlam dünyalarıyla buluşmaya kapı aralamaktadır. ${ }^{36}$

\subsubsection{Kıyâme 31-32}

Kıyame suresinde, bir takım yüzlerin kararacağından bahsedilir ve bunun sebebi olarak da

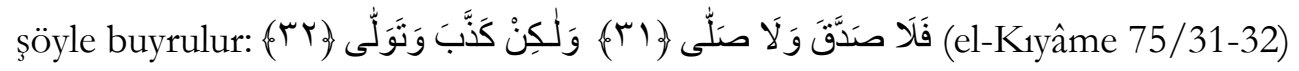

Bu iki ayete şu şekilde anlam verilir:

"Vaktiyle o hakka inanmamış, namaz da kılmamıştı. Aksine inkâr etmiş, haktan yüz çevirmişti.” (Kur'an Yolu Meali)

“O, (Peygamberi) doğrulamamış, namaz da kılmamıştı. Fakat yalanlamış ve yüz çevirmişti." (DİB Meali)

“(Artık son pişmanlık fayda etmez) çünkü (yaşadığı sürece) hakikati kabul etmedi ve (aydınlığa kavuşmak için) namaz kılmadı; tam tersine, hakikati yalanladı ve (ondan) uzaklaştı," (Muhammed Esed Meali)

Bu iki ayet, bağlamsal olarak bir birinin zıddı olan eylemlerden bahsetmektedir. İkinci ayetten yola çıkacak olursak: “Aksine inkâr etmiş, haktan yüz çevirmişti.” (el-Kıyâme 75/32) ayeti birinci

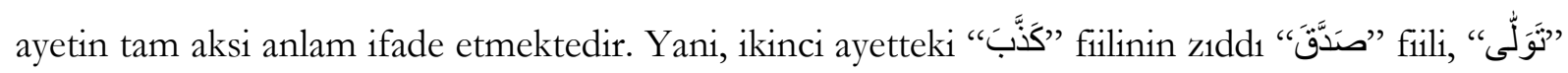

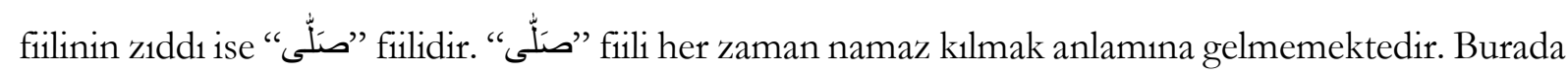

35 Râzî, Mefâtîhu'l-gayb, 30: 727.

36 Bu konuda yapılmış muhtelif çalışmalarda da bu makalede ulaştığımız sonuca varılmış ve makalemizde ortaya konulan anlamın daha uygun olduğu kanaati ifade edilmiştir. Bk. Ali Rıza Gül, "Kıyamet Suresi'nin 16-19'uncu Ayetlerine Yüklenen Geleneksel Yorumlar Üzerine", Ankara Üniversitesi İlabiyat Fakültesi Dergisi 44/2 (2003): 69-108. Ayrıca bk. Mustafa Ünver, "Murâdı İlâhîye Ulaşma Çabası Ekseninde Kıyâme Sûresi 16-19’un Komşu Âyetlerle İlgisizliği Vehmi Üzerine Bir Mülâhaza", Ondokuz. Mayıs Üniversitesi Ilabiyat Fakülttesi Dergisi, 14/14-15 (Haziran 2003): 207-220. 
"صَلْلىى" fiilinin anlamını bulmak için, ikinci ayetteki filin zıt anlamını almak gerekmektedir. Bu sebepten dolayı fiilin anlamı burada “yüz çevirmek” anlamındaki “" kelimesinin zıt anlamı olan “yönelmek," "uymak" ve "boyun eğmek"tir.

Fahreddin er-Râzî de bu ayetteki "sallâ" fiilinin anlamlarından birinin de "tevellâ"nın zıddı olduğunu belirtmiş ${ }^{37}$ ve Mâtürîdî̉ (ö. 333/944) de bu fiile "uymak" ve "teslim olmak" şeklinde mana vermiştir. ${ }^{39}$ Kur’an'da bu kelimenin kullanışına bakacak olursak, kelimenin farklı anlamlarda kullanıldığına şahit olmaktayız. Mesela, Râgıb el-İsfahânî4" (ö. V./XI. yüzyılın ilk çeyreği) "Onlar şöyle cevap verirler: Biz musallin olanlardan değildik" (el-Müddessir 74/43) ayetindeki "musallin" kelimesinin, "peygambere uyanlar" anlamına geldiğini haber vermiştir. ${ }^{41}$

Mâide suresinde: "Ey iman edenler! Sizden önce kendilerine kitap verilenlerden dininizi alaya alıp oyuncak edinenleri ve kâfirleri dost edinmeyin. Eğer müminler iseniz Allah'a karşı gelmekten sakının." (el-Mâide 5/57) buyrularak ehli kitabın dini alaya almasından ve dini değerler ile oyun oynamasından bahsedilir. Hemen sonrasındaki ayette ise aynı grubun namaza davet edildiğinde bu çağrıyı alay ve eğlence konusu yaptıklarından bahsedilir ve "Namaza çağırdığınız zaman onu alay ve eğlence konusu yaparlar. Bu, onların aklını kullanmaz bir topluluk olmalarındandır." (el-Mâide 5/58) buyrularak " "صلاة" kelimesinin anlamı din olarak öne ç1kar1lır. Her ne kadar " صلاة" kelimeinin anlamı namaz olarak şüyu bulmuşsa da Kur'an'daki kullanımında her zaman namaz anlamına gelmemektedir. Ahzâb suresinde: "Şüphesiz Allah ve melekleri Peygamber'e salât ediyorlar. Ey iman edenler! Siz de ona salât edin, selam edin.” (el-Ahzâb 33/56) ayetinde ifade edilen "صلاة" kelimesine namaz anlamı verme imkânı yoktur.

Bu durumda Kıyame suresindeki ayetin anlamının: “O, (Peygamberi) doğrulamamış ve ona uyup teslim olmamıştı. Fakat yalanlamış ve yüz çevirmişti." (el-Kıyâme 75/32) şeklinde olması, bağlama daha uygun olacaktır.

37 Bk. Râzî, Mefâtîhu'l-gayb, 30: 736.

38 Mâtürîdiyye mezhebinin kurucusu, müfessir ve fakihtir. Fazla bilgi için bk. Şükrü Özen, "Mâtürîdî", Türkiye Diyanet Vakf. İslam Ansiklopedisi (Ankara: TDV Yayınları, 2003), 28: 146-151.

39 Bk. Mâtürîdî, Tefsîru'l-Mâturî̀î, 10: 353.

40 Tam adı Ebü'l-Kāsım Hüseyn b. Muhammed b. el-Mufaddal er-Râgıb el-İsfahânî olup Arap dili âlimi, müfessir ve ahlak felsefecisidir. Hakkında fazla bilgi için bk. Ömer Kara, "Râgıb el-İsfahânî", Türkìye Diyanet Vakfı İslâm Ansiklopedisi (İstanbul: TDV Yayınlar1, 2007), 34: 398-401.

41 Râgib el-İsfahânî, "Sly", el-Müfredât fì garîbi'l-Kur'ân, thk. Safvân Adnân ed-Dâvûdî (Dimeşk: Dâru'l-kalem, 1412), 492. 


\subsection{Nebe' Suresi 31-34 ve 40. Ayetler}

\subsubsection{Nebe’ $31-34$}

Nebe' suresinde, kıyametin mutlaka kopacağı, insanların gruplar halinde Allah'ın huzuruna geleceği, hesaplarının görülmesinden sonra Allah'ın ayetlerini yalanlayanların hali ve karşılaşacakları cezalar açıklanmaktadır. Bundan sonra da hadiste belirtildiği gibi "Gözlerin görmediği, kulakların işitmediği ve hiçbir beşerin aklının [tam olarak] kavrayamayacağ1 türden nimetler", ${ }^{42}$ lütuflar ve ikramlardan bahsedilmekte ve Allah'a karşı sorumluluklarının farkında olanlar hakkında şöyle buyrul-

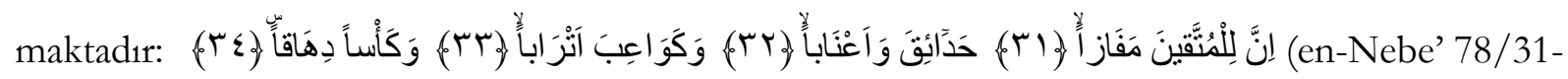
34). Bu dört ayet meallerde şu şekilde tercüme edilmiştir:

“İtaatsizlikten sakınmış olanlar için artık murada erme zamanıdır. Bahçeler, üzüm bağları; Gencecik yaşıt kızlar; İçki dolu kadehler.” (Kur’an Yolu Meali)

“Şüphesiz Allah'a karşı gelmekten sakınanlara bir kurtuluş, bahçeler, üzümler, kendileriyle bir yaşta, göğüsleri çıkmış genç kızlar ve dolu dolu kadehler vardır.” (DİB Meali)

“(Ama) Allah'a karşı sorumluluk bilinci taşıyanlar için büyük bir tatmin vardır: Muhteşem bahçeler ve bağlar, müthiş uyumlu harika eşler ve dolup taşan (mutluluk) kadehleri.” (Muhammed Esed Meali)

Yapılan tercümelere göre bu ayetlerde muttakiler için bahçeler bağlar, genç kızlar, yaşıt eşler ve dolu kadehlerden bahsedilir. Bağlar ile bağların üzümlerinden sıkılmış ve doldurulmuş kadehler arasına tercümelerde genç kızlar, yaşıt eşler diye yer alan "وَكَوَاعِبَ أَتْرَاباًاً ayeti girmiştir. Bu ayetin bağlam açısından incelenmesi sonucunda farklı anlamlara ulaşmak mümkün olacaktır.

Ayetlerin ilkinde "muttakiler" ifadesi geçmektedir ve bu kelime hem erkekler hem de kadınlar için kullanılan ortak bir kelimedir. Kur’an’da, kadınlarla ilgili özel bir mesele gündeme getirilmediği sürece, onlara ait müennes zamirler veya kullanımlar devreye sokulmaz. Eğer müzekker bir ifade kullanılmışsa bu, hem erkek hem de kadınları içine almaktadır. ${ }^{43}$ Dolayısıyla bu ayetlerde hem erkeklerden hem de kadınlardan muttaki olanlar için ortak bir mükâfattan bahsedilecektir.

Bu mükâfat bahçeler bağlar ve dolu kadehler olarak bildirilir. Bu ikisi arasında bir üçüncü mükâfat olarak "وَكَوَاعِبَ أَتْرَاباً، mükâfatından bahsedilir. Bu mükâfatın bağlama uygun olması için; erkek ve kadınlar için ortak bir mükâfat olması, bağ ve bahçe ile bağın üzümlerinden sıkılan suyla

42 Buhârî, "Bed'ü’l-Halk”, 8; Müslim, “el-Cennetü ve Sıfatü neîmihâ ve ehlihâ", 2-5.

43 Kur’an'ın hitap tarzına göre eğer hitap umuma aitse kastedilen mana da umumidir. Yani, "namaz kilın emri”, "Allah sizi yarattı", "Muttakiler"... gibi hitaplar hem kadınları hem de erkekleri kapsamaktadır. Bk. Zerkeşî, Burhân, 2: 217; Suyûtî, İtkân, 2: 43; Cerrahoğlu, Tefsir Usûlü, 192. 
doldurulmuş kadehlere uygun içerikte olması gibi iki şartın anlam içeriğinde bulunması gerekmektedir.

Yapılmış tercümelere baktı̆̆ımız zaman bu ayetin, "gencecik yaşıt kızlar” ve "gögüsleri çıkmış genç kızlar" anlamına gelmesi bağlama uygun değildir. Zira muttaki kadınlar için bu ifadenin mükâfat olarak tanımlanacak bir yönü yoktur. Üçüncü meal olan, "müthiş uyumlu harika eşler" tanımlaması ise erkek ve kadınlan da içine alması sebebiyle birinci bağlama uymaktadır. Bağlamdaki ikinci şart yönünden ise, bağlardan ve onun üzümlerinin suyuyla doldurulmuş kadehlerden bahsederken araya "genç kızlar”'ın veya “eş”lerin girmesi bağlama tam olarak uygun düşmemektedir.

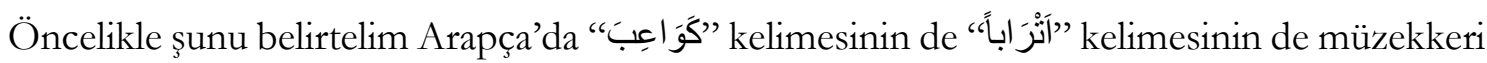
ve müennesi aynıdır yani bu kelimeler dişilik anlamı taşımamaktadır. Kâbe, etrafında tavaf edilen yer olması münasebetiyle "yuvarlak şekilli" anlamına da gelebileceğinden ${ }^{44}$ hareketle " kelimesine "yuvarlak şekilleri olan” anlamının verilmesi bağlam açısından herhangi bir problem ortaya çıkarmayacaktır. Buna göre bir önceki ayette belirtilen üzüm bağlarına atfen; yuvarlakımsı (كَ) اعَبَ) ve birbirine denk (آَترَاباً) anlamı esas alınarak ayetler: “Allah’a karşı sorumluluk bilinciyle hareket edenler için; bahçeler bağlar, hepsi birbirine denk yuvarlak şekilli üzümler ve dolup taşan kadehler vardır." (en-Nebe' 78/31-34) şeklinde de anlaşılabilir.

\subsubsection{Nebe' 40}

Nebe suresinin son ayetinde şöyle buyrulur:

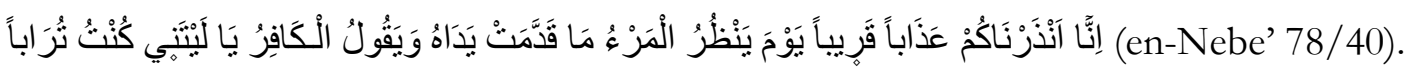

$\mathrm{Bu}$ ayet meallerde şu şekilde tercüme edilmiştir:

“Biz insanın önceden yapıp ettiklerine bakacağız, inkârcının da, 'Keşke toprak olsaydım!' diyerek dövüneceği gün gerçekleşecek olan yakın bir azaba karşı sizi uyardık.” (Kur'an Yolu Meali)

“Şüphesiz biz sizi, kişinin önceden elleriyle yaptıklarına bakacağı ve inkârcının, 'Keşke toprak olaydım!' diyeceği günde gerçekleşecek olan yakın bir azaba karşı uyardık.” (DİB Meali)

“Gerçek şu ki, Biz sizi yakındaki bir azaba karşı uyarmaktayız; insanın ilerisi için yapıp ettiklerini (açıkça) göreceği ve hakikati inkar edenin: 'Eyvah, keşke toprak olsaydım..!' diyeceği Gün(ün azabina)!" (Muhammed Esed Meali)

44 Kevâib, كعب (Kẩb) kökünden türemiş, كاعب (Kâib) ism-i fâilinin çoğuludur. Dört köşeli kübik varllkları ifade eder. Kâbe, ismini, kübik yapısından dolayı bu kelimeden almıştır. Araplar kübik şekilli olan tüm binaları are (Ka’be) olarak isimlendirir. Bu kelime dairemsi yapıları da kapsamaktadır. Tavafın Hâtim’in dışından yapılması da bunu teyit eder. Ayrıca Ka'be kelimesi, etrafinda tavaf edilen; yani yuvarlak tipli odalar olarak da tarif edilir. Bk. İbn Manzûr, "Kab", Lisânü'l-Arab, 1: 718-719. 
Bu ayette: "Keşke toprak olsaydım!" diyecek olan inkârciyı belirten “"الََْفِرُ" (el-kâfiru) kelimesinin başında belirlilik edatı olan harfi tarif vardır. Örnek olarak aldığımız her üç mealde de bu edat, inkâr eden tüm insan cinsini içine alacak ve her kâfiri kapsayacak şekilde cinsiyye olarak tercüme edilmiştir. Bu durumda bütün kâfirlerin, toprak olduktan sonra dirilmeyi inkâr etmelerinden dolay1 "keşke toprak olup kalsaydım” diyeceği anlaşılmakta ve bu anlamın önünde herhangi bir engel de bulunmamaktadır. Ancak buradaki harfi tarif ahdiyye bağlamında kabul edilip ayet buna göre yorumlandığında karşımıza yine bütün kâfirleri bir başka yönden kapsayan farklı bir mana çıkar. Buna

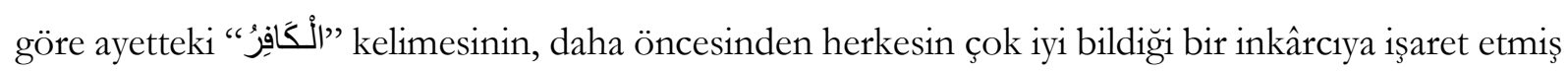
olması gerekmektedir. Zira ayet bu inkârcının ahirette "topraktan yaratılmış olma” özlemini dile getirdiğini bildirmektedir. Bağlamı daha iyi belirlemek için konuyla ilgili başka ayetlerden yardım alacak olursak şu ayetler karşımıza çıkacaktır:

“Hani meleklere, “Âdem için saygı ile eğilin” demiştik de İblis hariç bütün melekler hemen saygı ile eğilmişler, İblis (bundan) kaçınmış, büyüklük taslamış ve kâfirlerden olmuştu.” (el-Bakara 2/34).

“Allah, ‘Sana emrettiğim zaman seni sayg1 ile eğilmekten ne alıkoydu?’ dedi. (O da) 'Ben ondan hayırlıyım. Çünkü beni ateşten yarattın. Onu ise çamurdan yarattın’ dedi.” (el-A'râf 7/12).

"İblis, 'Ben ondan daha hayırlıyım. Beni ateşten yarattın, onu ise çamurdan yarattın' dedi." (Sâd 38/76).

Bu üç ayette de Allah'in, Âdem'e secde edilmesi şeklindeki emrine uyan meleklerin haricinde, emre itaat etmeyen, kendisinin ateşten yaratıldığını öne sürerek, topraktan yaratılmış bir varllğa secde etmeyeceğini beyan eden ve böylece kâfir olan bir varlıktan; İblisten söz edilmektedir. Bu olay üzerine İblis Allah'ın rahmetinden kovulmuş ve lanetlenmiştir. ${ }^{45}$

O zaman bu varlık, kıyamet gününde amellerin değerlendirilip, varlıkların önceden yapıp ettiklerine bakılıp herkes hakkında karar verileceğinde "keşke ben de topraktan yaratılmış olsaydım, ateşten yaratılmam beni kibre sevk etmeseydi de Allah’ın emrine karşı çıkmasaydım” diyerek pişmanlık gösterecektir. İşte söz konusu ayette anlatılanlardan biri de budur. ${ }^{46}$

Bu durumda ayetin manası: "Biz insanın önceden yapıp ettiklerine bakacağız, Şeytanın da, "Keşke ben de toprak(tan yaratılmış) olsaydım (da kibirlenerek imandan vazgeçmeseydim!)" diyerek dövüneceği gün gerçekleşecek olan yakın bir azaba karşı da sizi daha önce uyarmıştık.” (en-Nebe’

45 Bk. el-A'râf 7/13; Sâd 38/77.

46 Bk. Râzî, Mefâtîhu'l-gayb, 31: 27; İbn Atiyye el-Endelüsî, el-Mubarreru'l-vecîz fî tefî̀ri'l-Kitâbi'l-Azî̌z, thk. Abdüsselam Abdüşşâfîi Muhammed (Beyrut: Daru'l-kütübi'l-ilmiyye, 1422), 5: 429; Kurtubî, el-Câmin li abkâmi'l-Kur'ân, 19: 189; Ebû Hayyân el-Endelüsî, el-Babru'l-mubît fìt-tefsîr, thk. Sidkî Muhammed Cemîl (Beyrut: Dâru'l-fikr, 1420), $10: 391$. 
78/40) şeklinde de anlaşılabilir. Böylece önemli klasik tefsirlerimizde de anlamlardan birisi olarak vurgulandığı şekilde bir mana zenginliği meydana gelmiş olur.

\subsection{Alak Suresi 2. Ayet}

Kur'an'da: خَلَقَ الْإِنسَانَ مِنْ عَلَقِ (el-Alak 96/2) buyrulmuştur. Bu ayetin çevirilerine baktığımız zaman şu şekilde mana verildiğini görürüz:

“O, insanı alaktan (asılıp tutunan zigottan) yaratmıştır.” (Kur’an Yolu Meali)

“O, insanı "alak" dan yarattı.” (DİB Meali)

“İnsanı bir yumurta hücresinden yaratan!" (Muhammed Esed Meali)

Ayetteki “'الْْنْسَانَ" (el-insân) kelimesinin başındaki "el” harfi tarifi, her üç mealde de "cinsiyye" kabul edilerek "insan cinsi”" olarak çevrilmiştir. İlk bakışta bu çeviri bir problem olarak görünmese de, bağlamı göz önüne aldığımızda çevirinin farklı şekillerde de yapılabileceği görülecektir. Zira “ 'كََّّ الِالِنْسَانَ “' lafzının, müfessirlerin hemen hepsi tarafindan Ebû Cehil'e işaret ettiği yönünde kanaat bildirmeleri ve 6'nc1 ve 19'uncu ayetlerin bu kişi hakkında indiğini söylemeleri ${ }^{47}$ göz önüne alındığında, harfi tarifin cinsiyye olarak değil, “ahdiyye” olarak ele alınması gerektiği noktasında ipuçları vermektedir. Bu durumda “'الِْنْسَانَ" lafzının anlamı genel olarak insan cinsi veya insanlar olmayıp, bilinen bir kişi veya grup olma ihtimali ortaya çıkacaktır.

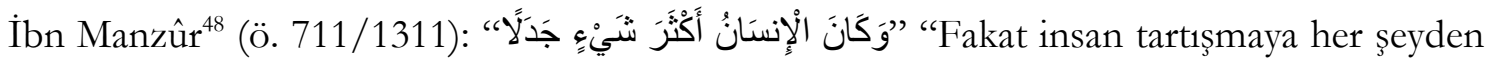

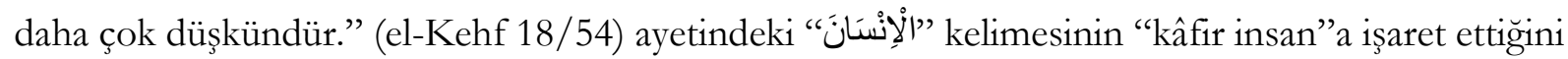
ifade eder. ${ }^{49}$ Zaten Kur’an'’n genel bağlamı içerisinde “"الْْنِسَانَ" kelimesi yirmi beş farklı kişiye atfen kullanılmaktadır. Bunlardan beşini Müslüman kişiler, yirmisini Kureyş’in siyasi ve ekonomik gücü

47 Bk. Taberî, Camiu'l-beyân, 24: 523-524; Muhammed b. Ali el-Vâhıdî, el-Vecî́ fì tefsîri'l-Kitâbi'l-Ažřr, thk. Safvân Adnân Dâvûdî (Dımeşk: Dâru'l-kalem, 1415), 1217-1218; İbn Atiyye, el-Muharrerü'l-Vecîy, 5: 502; Râzî, Mefâtîhu'l-gayb, 32 : 219.

48 Lisânü’l-Arab adlı ansiklopedik sözlüğüyle tanınan dil âlimi, edip ve Şâfî̀ fakihidir Fazla bilgi için bk. Hulusi Kılıç, “İbn Manzûr”, Türkiye Diyanet Vakfi İlâm Ansiklopedisi (Ankara: TDV Yayınları, 1999), 20: 171-172.

49 İbn Manzûr, "Ens”, Lisânü'l-Arab, 6: 10. 
elinde bulunduran inkârcı takımı oluşturmaktadır. Bu yirmi inkârcıdan beşini ise meşhur müşriklerden Velid b. Muğîre ${ }^{50}$ (ö. 1/622), Ebû Cehil ${ }^{51}$ (ö. 2/624), Nadr b. Hâris ${ }^{52}$ (ö. 2/624), Ukbe b. Ebû Muayt $^{53}$ (ö. 2/624) ve Übey b. Halef ${ }^{54}$ (ö. 3/625) oluşturmaktadır. ${ }^{55}$

Alak suresi 3'üncü ayette Allah'ın kendi zatını "ekrem" olarak nitelemesinde, bazı rivayetlere göre kendisini çok değerli, şerefli bir kimse olarak tanıtan Ebû Cehil'e bir gönderme vardır ${ }^{56}$ ve burada Allah: "Kerîmlik sıfatı sana değil bana aittir." demektedir. Duhân suresindeki: “ذُقْ إنَّكَ اَنْتَ "الْعَزيزُ الْكَريُُ "(Madem) sen güçlü ve değerlisin; (o zaman) tat bakalım (azabı)!” (ed-Duhân 44/49) ayeti bu manayı destekler mahiyettedir. Bu bilgi, Alak suresi 3'üncü ayetteki "ekrem" kelimesinin, “cömertlik" yanında "şerefli olmak" anlamına geldiğine, dolayısıyla sürenin ilk beş ayetinin de Ebû

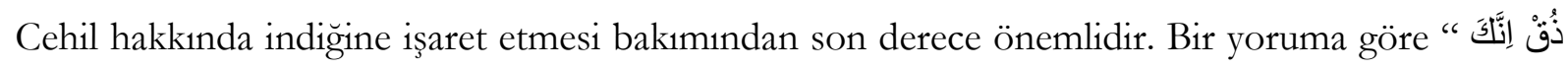

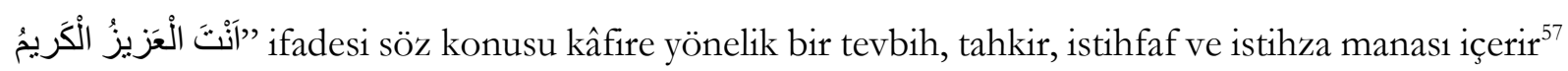
ve bir bakıma "İzzet ve şeref kim, sen kim?" anlamına gelir. ${ }^{58}$

50 Tam adı Ebû Abdişems el-Velîd b. el-Mugīre b. Abdillâh el-Mahzûmî’dir. İslâm'ın ve Hz. Peygamber'in azılı düşmanlarındandır. Fazla bilgi için bk. Mustafa Fayda, "Velîd b. Mugîre", Türkiye Diyanet Vakefi İslâm Ansiklopedisi (İstanbul: TDV Yayınlar1, 2013), 43: 33-34.

51 Asıl adı Ebü'l-Hakem Amr b. Hişâm b. Mugîre el-Kureşî el-Mahzûmî’dir. Ebû Cehil ismiyle anılır. Hz. Peygamber'in ve Müslümanların azılı düşmanlarındandır. Fazla bilgi için bk. Mehmet Ali Kapar, "Ebû Cehil”, Türkiye Diyanet Vakfi İslâm Ansiklopedisi (Ankara: TDV Yayınları, 1994), 10: 117-118.

52 Tam adı en-Nadr b. el-Hâris b. Alkame b. Kelede el-Kureşî’dir. Hz. Peygamber'in ve Müslümanların azılı düşmanlarındandır. Fazla bilgi için bk. İrfan Aycan, "Nadr b. Hâris", Türkìye Diyanet Vakefi İslâm Ansiklopedisi (İstanbul: TDV Yayınlar1, 2006), 32: 280-281.

53 Tam adı Ebü'l-Velîd Ukbe b. Ebî Muayt b. Ebî Amr b. Ümeyye el-Ümevî'dir. Hz. Peygamber'in ve İslâm'ın az1lı düşmanlarındandır. Fazla bilgi için bk. İsmail Yiğit, "Ukbe b. Ebû Muayt”, Türkiye Diyanet Vakefi İslâm Ansiklopedisi (İstanbul: TDV Yayınları, 2012), 42: 63-64.

54 Tam adı Übey b. Halef b. Vehb el-Cumahî'dir. Hz. Peygamber'in ve İslâm’ın azılı düşmanlarındandır. Fazla bilgi için bk. Ahmet Önkal, “Übey b. Halef”, Türkiye Diyanet Vakfı İslâm Ansiklopedisi (İstanbul: TDV Yayınlar1, 2012), 42: 272.

55 el-insan kelimesinin yirmi beș farklı kullanımı șu șekildedir: 1- Âdem 2- Âdemoğulları 3- Ebû Bekir 4- Sa'd b. Ebû Vakkâs 5- Velid b. Mugîre 6- Kart b. Abdullah 7- Ebû Cehil 8- Nadr b. Hâris 9- Bersîsa el-Âbid 10- Bedî’ b. Verkâ 11- Ahnes b. Şüreyk 12- Esved b. Abdülesed 13- Ayyâş b. Ebû Rebîa 14- Kelde b. Üseyd 15- Ukbe b. Ebû Muayt 16- Ebû Tâlib b. Abdülmuttalib 17- Utbe b. Ebû Leheb 18- Ady b. Rebîa 19- Utbe b. Rebîa 20- Ümeyye b. Halef 21- Übey b. Halef 22- Hâris b. Amr 23- Ebû Huzeyfe b. Abdullah 24- Ebû Leheb b. Abdüluzzâ 25- Kâfir kişi. Bk. Ebü'l-Ferec İbnü'l-Cevzî, "Bâbü'l-insân”, Nü̈hetül-A'yüni'n-nevâzir fì ilmi'l-vüin̂hi ve'n-nezâir, thk. M. Abdulkerîm Kâzım er-Râzî (Beyrut: Müessesetü'r-risâle, 1404/1984), 176-183.

56 Ebû Cehil Hz. Peygamber'e hitaben: 'Mekke ve havalisindeki şu dağlar arasında benden daha kerîm/şerefli, değerli bir kimse yoktur. Sen ve Rabbin benim gibisini var edemezsiniz.' dediği rivayet edilmektedir. Râzî, Mefâtîbu'l-gayb, 27: 664. Ayrica bk. Taberî, Camiu'l-beyân, 22: 48; Ebû İshâk Muhammed b. İbrahim es-Sa'lebî, el-Kesff ve'l-beyân an teffîri'l-Kur'ân, thk. İmâm Ebî Muhammed b. Âşûr (Beyrut: Dâru ihyâi't-türâsi'l-Arabî, 1422/2002), 8: 356; Muhammed b. Ali el-Vâhıdî, el-Vasît fî̀ tefsîri'l-Kur'âni'l-Mecîd, thk. Âdil Ahmed Abdülmevcûd v.dğr. (Beyrut: Dâru'l-Kütübi'l-İlmiyye, 1415/1994), 4: 92; Vahıdî, el-Vecî̀, 986; Ebü’l-Ferec İbnü'l-Cevzî, Zâdü'l-mesîr fî̀ ilmi't-tefsîr, thk. Abdürrezzâk el-Mehdî (Beyrut: Dâru'l-kitâbi'l-Arabî, 1422), 4: 94; Ebû Muhammed el-Hüseyn el-Begavî, Meâlimü'ttenzîl fî tefsîri'l-Kur'ân, thk. Muhammed Abdullah en-Nemr v.dğr. (b.y.: Dâru't-Tayyibe, 1417/1997), 7: 236; Kurtubî, el-Câmi', 16: 151; Ebû Hayyân, el-Babru'l-Mubît, 10: 508.

57 Râzî, Mefâtîhu'l-gayb, 27: 664; İbnü'l-Cevzî, Zâdü'l-mesîr, 4: 94; Begavî, Meâlimü't-tenzîll, 7: 236; Kurtubî, el-Câmi', 16 : 151.

58 Mustafa Öztürk - Hadiye Ünsal, "Evvelü Mâ Nezel Meselesi Bağlamında Erken Dönem Mekkî Surelerin Kavram ve Anlam Dünyası”, Kur'an Nüzûlünün Mekeke Dönemi Sempozyumu Bildirileri (Çorum, 29 Haz̧iran - 01 Temmuz. 2012), ed. Mesut Okumuş (Çorum: Çorum Belediyesi Kültür Yayınları, 2013), 135-136. 
Surede: “Kalemle (yazmay1) öğreten” (el-Alak 96/4) buyrulmas1, “الِِنْنَانَ" olarak bahsedilen kişinin daha önceden okuma yazma biliyor olmasını akla getirir. Hz. Peygamber'in okuma yazma bilmediğinden ${ }^{59}$ yola çıkılacak olunursa, burada muhatabın Hz. Peygamber olmayıp okuma yazma bilen birisi olduğu ve Allah'ın, inanmayıp nankörlük eden o kimseye bu nimetini hatırlattı̆̆ da anlaşılabilir.

Diğer taraftan, Ebu Hayyân'ın Alak suresi 6'ncı ayetin başındaki “"كََّّ" (kellâ) edatı hakkında: “Allah'ın kendisine bahşettiği nimetlere azgınlık göstermek ve inkârcılıkla haddi aşmak suretiyle nankörlük gösteren kimseyi bundan men etmek manası taşır. Gerçi bu ayetin öncesinde kâfir olan bir insanın bahsi geçmemiştir; fakat sözün bağlamı buna delalet etmektedir.” şeklinde izahta bulunması ${ }^{60}$ ayetin bağlamı hakkında önemli bir malumat vermektedir.

Bütün bunlara rağmen müfessirler, Alak suresi 1-5’inci ayetlerini ilk nazil olan Kur' an ayetleri olarak kabul ettiğinden dolay1, bu ayetlerde geçen “"الإِنْسَانَّ" lafzının genel manada insanoğluna karş1lık geldiği sonucuna ulaşmışlardır. ${ }^{61}$ Ancak bu durum, yukarıda belirtilen gerekçeler sebebiyle bağlamla tam olarak örtüşmemektedir.

Ayetleri baştan itibaren okuyup bağlamı içerisinde mana verecek olursak karşımıza şöyle bir anlamın çıkması da muhtemeldir: "Yaratan Rabbinin adıyla oku! Ki o, (inkâr eden) insanı "alak"tan / "yumurta hücresi”nden yarattı. (O inkârcıya) bildir (ki o, kerîm değildir). Asıl Kerîm olan Rabbindir." (el-Alak 96/1-3).

\section{Sonuç}

Kur’an ayetlerini, kendi bağlamı içerisinde değerlendirmek, onu doğru anlamanın ve sahih bir şekilde yorumlamanın en önemli ilkelerindendir. Kur'an’’ doğru anlamak, doğru din anlayışının temel ögesidir. Zaten Kur'an'ı okuma, anlama ve yorumlama faaliyetlerinin ana gayesi de doğru din bilgisine ulaşmaktır.

59 “Onlar, yanlarındaki Tevrat ve İncil’de vasıflarını yazılı buldukları o ümmî nebî olan peygambere tâbi olanlardır. O (peygamber), onlara iyiliği emreder, onları kötülükten sakındırır...” (el-A'raf 7/157). "De ki: 'Ey insanlar! Şüphesiz ki ben sizin hepinize, göklerin ve yerin hükümrânlığ kendisine ait olan, kendisinden başka hiç bir ilâh olmayan, hayat veren ve öldüren Allah'ın gönderilmiş elçisiyim. O halde Allah'a iman edin. Allah'a ve kelimelerine iman eden ümmî nebi olan elçisine de iman edin ve ona uyun ki, doğru yolu bulmuş olasınız.' " (el-A'raf 7/158). "Sen bundan önce ne bir Kitâp okuyor (tilavet ediyor), ne de elinle onu yazıyordun. Öyle olsaydı, bâtıla uyanlar elbette şüpheye düşerlerdi." (el-Ankebût 29/48).

60 Ebû Hayyân, el-Babru'l-Mubît, 10: 508.

61 Mustafa Öztürk - Hadiye Ünsal, "Evvelü Mâ Nezel Meselesi Bağlaminda Erken Dönem Mekkî Surelerin Kavram ve Anlam Dünyası", 128. Bu makalede ilk inen ayetlerin Alak suresinin ilk beş ayeti olmayıp, Fâtiha suresi olduğu teferruatlı olarak ele alınır ve konuyla ilgili uzun mütalaalar serdedilir. Dolayısıyla Alak suresi ikinci ayetindeki "elinsân” kelimesinin de, genel manada insan cinsi değil, Ebû Cehil olduğu ifade edilir. 
Kur'an'ı doğru anlamak için bağlamın önemi çok eskilerden beri vurgulanmasına rağmen maalesef buna aynı oranda riayet edilmediğine şahit olunabilmektedir. Öteden beri Tefsir Usulünün önemli konularından bir tanesinin de siyâk, sibâk, Münasebetü’l-Kur'an ve Esbabı Nüzul gibi konular olmasına rağmen Kur’an tefsiri üzerinde çalışanlar, bağlamı önemsemeyen parçacı yaklaşımlardan bir türlü uzak kalamamışlardır. Kur'an yorumcularına düşen, öncelikle, ayetin kendi bağlamı içerisinde ne anlama geldiğini tespit etmektir. Onu yorumlamak ve kapsamını belirlemek daha sonraki bir iş olmalıdır.

Bu çalışmada Kur'an ayetlerinden örneklemeler yapıp bazı ayetlerin bağlamını belirleyerek bu bağlama uygun anlamlar ortaya konmaya çalışılmıştır. Bunun sonucunda isimlerin başındaki harfi tarifin bağlamın tespit edilmesinde önemli rol oynadığ1 ve bu tespit sonucunda hem daha doğru hem de daha zengin anlamlara ulaşmanın mümkün olabileceği ortaya çıkmıştır. Aynı zamanda ayetler arasındaki münasebetin, pasajlar arasındaki konu bütünlügünün tespitinde önemli katkı sağlayacağı da belirgin hale gelmiştir. Bağlam ile sadece siyakın kastedilmemesi gerektĭgi, bunun yanında ayetle alakalı olan çevresel faktörlerin de göz önüne alınmasının anlam zenginliğine yol açacağı, hatta çoğu zaman bu durumun anlamın ortaya çıkması için kilit rol oynadığı da anlaşılmıştır.

Sonuçta, tüm mealleri incelemenin imkânsızlığı münasebetiyle bunlardan en yaygın kullanıldığı var sayılan bazıları incelenerek, bu meallerde elde edilen anlamlardan daha farklı olanlarına ulaşarak, ayetlerin bağlamında ele alındığında farklı anlamların ortaya konulabileceğine şahit olunmuştur. 


\section{Kaynakça}

Abdel Haleem, Muhammad. "The Role of Context in Interpreting and Translating the Qur'an", Journal of Qur'anic Studies 20/1 (2018): 47-66.

Aksan, Doğan. Her Yönüyle Dil. Ankara: TDK Yayınları, 1995.

Arslan, Giyasettin. “Türkçe Kur’ân-1 Kerîm Meallerinde Hedef Dilin Önemi”. Furat Üniversitesi İlabiyat Fakültesi Dergisi 8 (2003): 27-44.

Ateş, Avnullah Enes. Kur'an Yorumunda Siyakın Yeri-Zemahşerî Öz̧elinde-, İstanbul: Kitâbî Yayınları, 2018.

Ateş, Süleyman. Kur'ân-ı Kerîm Tefsiri. İstanbul: Yeni Ufuklar Neşriyat, 1988.

Aycan, İrfan. "Nadr b. Hâris". Türkiye Diyanet Vakfi İslâm Ansiklopedisi. 32: 280-281. İstanbul: TDV Yayınları, 2006.

Bakkal, Ali. Kur'ân'ı Anlamada Siyak-Sibakın Önemi. İstanbul: İlim Yayma Vakfı Kur'an ve Tefsir Akademisi Yayınları, 2009.

Begavî, Ebû Muhammed el-Hüseyn. Meâlimü't-tenzîllfît tefsîri'l-Kur'ân. Thk. Muhammed Abdullah enNemr v.dğr. 4. Bask1. 8 Cilt. b.y.: Dâru’t-Tayyibe, 1417/1997.

Bidav, Y1lmaz. Arap Dilinde Zâid Harfler. Yüksek Lisans Tezi, Selçuk Üniversitesi, 2015.

Buhârî, Muhammed b. İsmâil. Sabîhu'l-Bubârî. Thk. Muhammed Züheyr b. Nâsır en-Nâsır. 9 Cilt. b.y.: Dâru tavki'n-necât, 1422.

Cerrahoğlu, İsmail. Tefsir Usûlü. Ankara: TDV Yayınları, 1988.

Daşkıran, Yaşar. “Temmâm Ḥassân’ın Dil Anlayışı: Karineler Teorisi”. Ankara Üniversitesi İlahiyat Fakültesi Dergisi 56/2 (2015): 149-163.

Deliçay, Tahsin. -Koç, Sadık. “Arap Dilinde Harf-i Ta'rif'. Fırat Üniversitesi Sosyal Bilimler Dergisi 12/2 (2002): 191-210.

Demirci, Muhsin. Tefsir Usûlü. 41. Baskı. İstanbul: M. Ü. İlahiyat Fakültesi Vakfi Yayınları, 2015.

Endelüsî, Ebû Hayyân. el-Babru'l-muhît fi't-tefsîr. Thk. Sidkî Muhammed Cemîl. 10 Cilt. Beyrut: Dâru'l-fikr, 1420.

Fayda, Mustafa. "Velîd b. Mugîre". Türkiye Diyanet Vakfi İlâm Ansiklopedisi. 43: 33-34. İstanbul: TDV Yayınları, 2013.

Gökkır, Necmettin. "Tefsir Usulünde "Lafız-Mana" ilişkisinin Tespiti ve Bağlam Bilgisinin Önemi”. Kur'an İlimleri ve Tefsir Usulï (Ağustos 2009): 333-344.

Gül, Ali Rıza. "Kıyamet Suresi'nin 16-19'uncu Ayetlerine Yüklenen Geleneksel Yorumlar Üzerine”. Ankara Üniversitesi İlabiyat Fakültesi Dergisi 44/2 (2003): 69-108. 
Gürkan, Nejdet. “Arapçada "El” Takısı ve Fonksiyonları”. Ekev Akademi Dergisi 18 (2004): 357374.

Güven, Şahin. Kur'ân'ın Anlaşılması ve Yorumlanmasında Çokanlamlılı Sorunu. İstanbul: Denge Yayınlar1, 2005.

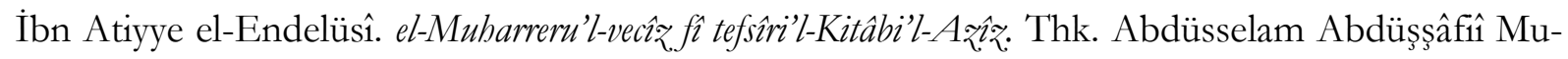
hammed. 6 Cilt. Beyrut: Daru'l-kütübi'l-ilmiyye, 1422.

İbn Hişâm, Ebû Muhammed Abdullâh Cemâleddîn b. Yûsuf b. Ahmed. Mugini'llebîb 'an kutubi'léârîb. Thk. Mâzin el-Mübârek - M. Ali Hamdullah. 6. Baskı. Dımeşk: Dâru’l-fikr, 1985.

İbn Manzûr, Ebü'l-Fadl Cemâlüddin. "Svk”. Lisânül-Arab. 3. Baskı. 15 Cilt. Beyrut: Dâru Sâdır, 1414.

İbn Teymiyye, Takiyyuddin. Mukaddime fî Usuli't Tefsir. Beyrut: Dâru mektebeti'l-hayât, 1490/1980.

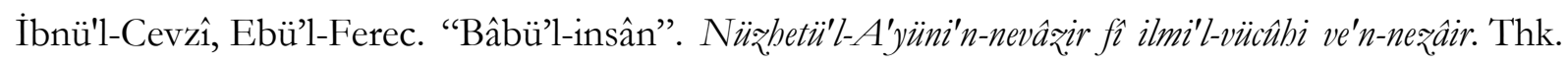

M. Abdulkerîm Kâzım er-Râzî. Beyrut: Müessesetü'r-risâle, 1404/1984.

İbnü'l-Cevzî, Ebü'l-Ferec. Zâdü'l-mesîr fì ilmi’t-tefsîr. Thk. Abdürrezzâk el-Mehdî. 4 Cilt. Beyrut: Dâru'l-kitâbi'l-Arabî, 1422.

İsfahânî, Râg1b. "Sly”. el-Müfredât fî garîbi'l-Kur'ân. Thk. Safvân Adnân ed-Dâvûdî. Dımeşk: Dâru'lkalem, 1412.

İslamoğlu, Mustafa. Kur’an Sûrelerinin Kimliği. 11. Baskı. İstanbul: Akabe Vakfi Yayınları, 2011.

Kapar, Mehmet Ali. "Ebû Cehil”. Türkiye Diyanet Vakefı İslâm Ansiklopedisi. 10: 117-118. Ankara: TDV Yayınlar1, 1994.

Karadâvî, Yusuf. “Kur’ân Tefsirinde İdeal Yöntem”. Trc. Muhittin Akgül. Diyânet İlmî Dergi 38/3 (2002): 57-90.

Karaman. Hayreddin, - Çağrıc1, Mustafa. - Dönmez, İ. Kâfi. - Gümüş, Sadrettin. Kur'an Yolu Türkẹce Meal ve Tefsir. Ankara: DİB Yayınları, 2007.

Karsl1, İlyas. - Kaplan, Ahmet. "Dilde Anlam ve Karine İlişkisi”. Recep Tayyip Erdoğan Üniversitesi İlabiyat Fakültesi Dergisi 10 (2016): 7-27.

Kılıç, Hulusi. "İbn Manzûr”. Türkiye Diyanet Vakefı İslâm Ansiklopedisi. 20: 171-172. Ankara: TDV Yayınları, 1999.

Kılıç, Ünal. "Peygamberimizin Risalet Öncesi Geçim Durumu”. İstem 4 (2004): 189-200.

Kurtubî, Ebû Abdillah Şemsüddin. el-Câmiu li abkâmi'l-Kur'ân. Thk. Ahmed el-Berdûnî - İbrahim Etfîş. 3. Baskı. 20 Cilt. Kahire: Dâru’l-kütübi'l-Mısriyye, 1384/1964.

Mâtürîdî, Ebû Mansûr. Tefsîru'l-Mâturîtî-Te'vîlâtü ebli's-sünne. Thk. Mecdî Bâsellûm. 10 Cilt. Beyrut: Dâru'l-kütübi'l-ilmiyye, 1426/2005. 
Mukâtil b. Süleymân b. Beşîr el-Ezdî, Ebü’l-Hasen. Tefsîru Mukâtil b. Süleymân. Thk. Abdullah Mahmûd Şehhâte. 5 Cilt. Beyrut: Dâru İhyâi't-türâs, 1423.

Müslim b. Haccâc. Sabîh. Thk. Muhammed Fuâd Abdülbâkî. 5 Cilt. Beyrut: Dâru ihyâi't-türâsi'lArabî, ts.

Nesefî, Ebü'l-Berekât Abdullah b. Ahmed b. Mahmûd Hâfizüddin. Tefsîru'n-Nesefî (Medârikü't-ten₹̨ill ve hakâiku't-te'vîl). Thk. Yûsuf Ali Bedîvî. 3 Cilt. Beyrut: Dâru'l-kalem et-tayyib, 1419/1998.

Ömer, Temmâm Hassan. el-Lüğatu'l Arabiyye Ma'nâhâ ve Mebnâhâ. 5. Bask1. Beyrut: Âlemü’l Kütüb, $1427 / 2006$.

Önkal, Ahmet. “Übey b. Halef”. Türkiye Diyanet Vakfi İslâm Ansiklopedisi. 42: 272. İstanbul: TDV Yayinlar1, 2012.

Özen, Şükrü. "Mâtürîlî”. Türkiye Diyanet Vakfı İslâm Ansiklopedisi. 28: 146-151. Ankara: TDV Yayinlari, 2003.

Öztürk, Mustafa. -Ünsal, Hadiye. “Evvelü Mâ Nezel Meselesi Bağlamında Erken Dönem Mekkî Surelerin Kavram ve Anlam Dünyası”. Kur'an Nüəûlünün Mekke Dönemi Sempozyumu BildiriLeri (Çorum, 29 Hą̧iran - 01 Temmu乏 2012). Ed. Mesut Okumuş. Çorum: Çorum Belediyesi Kültür Yayınları, 2013.

Râzî, Fahruddin. Mefâtîbu'l-gayb - Tefsîru'l-kebîr. 3. Bask1. 32 Cilt. Beyrut: Dâru ihyâi't-türâsi'l-Arabî, 1420.

Sa'lebî, Ebû İshâk Muhammed b. İbrahim. el-Keșf ve'l-beyân an tefsiri'l-Kur'ân. Thk. İmâm Ebî Muhammed b. Âşûr. 10 Cilt. Beyrut: Dâru ihyâi't-türâsi'l-Arabî, 1422/2002.

Suyûtî, Celâlüddin. el-İtkân fì ulûmi'l-Kur'ân. 2 Cilt. Beyrut: Dâru'l-ma'rife, ts.

Taberî, Muhammed b. Cerîr. Camiu'l-beyân fí te'vîli'l-Kur'ân. Thk. Ahmed Muhammed Şâkir. 24 Cilt. b.y.: Müessesetü'r-risâle, 1420/2000.

Tirmizî. Şemâil-i Şerîf Tercemesi. Trc. Muhammed Raif Efendi. Sad. Bekir Başarıcı. Konya: İhya Yayinlar1, ts.

Tiyek, Fatih. Kur'an'ı Anlamada Bağlamın Rolü ve Meallerdeki Bağlamsal Sorunlar. Ankara: Ankara Okulu Yayınlar1, 2015.

Uzun, Nihat. "Bağlamı Göz Ardı Etmek: Siyâsî Mücadelelerde Âyetlerin Kullanımı”. Atatük Üniversitesi İlahiyat Fakültesi Dergisi 37 (2012): 1-28.

Ünver, Mustafa. Kur'an'ı Anlamada Siyakın Rolü. Ankara: Sidre Yayınları, 1996.

Ünver, Mustafa. "Murâdı İlâhîye Ulaşma Çabası Ekseninde Kıyâme Sûresi 16-19’un Komşu Âyetlerle İlgisizliği Vehmi Üzerine Bir Mülâhaza". Ondokuz Mayıs Üniversitesi İlahiyat Fakültesi Dergisi 14 / 14-15 (Haziran 2003): 207-220. 
Ünver, Mustafa. “Tefsirin Temel Bir İlkesi Olarak Siyaka Riayet -Elmalılı Tefsiri Örneği_“. Tefsir Araștormalarn Dergisi 1 (Nisan 2017): 73-120.

Vâhıdî, Muhammed b. Ali. el-Vasît fì tefsîri'l-Kur'âni'l-Mecîd. Thk. Âdil Ahmed Abdülmevcûd v.dğr. 4 Cilt. Beyrut: Dâru'l-kütübi'l-ilmiyye, 1415/1994.

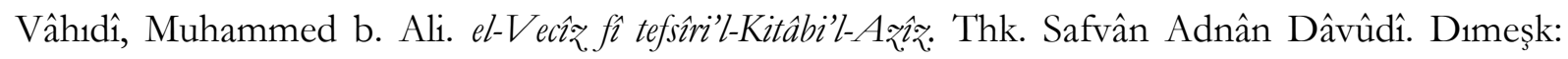
Dâru'l-kalem, 1415.

Yaşaroğlu, M. Kâmil. "Müddessir Sûresi”. Türkiye Diyanet V akefi İslâm Ansiklopedisi. 31: 463-464. İstanbul: TDV Yayınları, 2006.

Yaşaroğlu, M Kâmil. "Müzzemmil Sûresi”. Türkiye Diyanet Vakfı İslâm Ansiklopedisi. 32: 252. İstanbul: TDV Yayınları, 2006.

Yiğit, İsmail. "Ukbe b. Ebû Muayt". Türkiye Diyanet Vakfı İslâm Ansiklopedisi. 42: 63-64. İstanbul: TDV Yayınlar1, 2012.

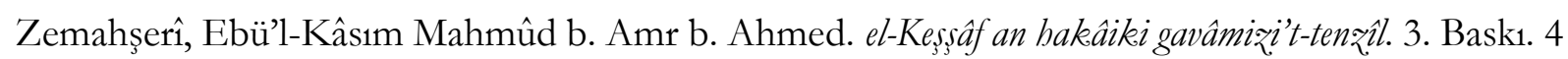
Cilt. Beyrut: Dâru'l-kitâbi'l-Arabî, 1407.

Zerkeşî, Bedruddin. el-Burbân fî ulûmi'l-Kur'ân. 4 Cilt. Beyrut: Dâru'l-ma'rife, 1376/1957. 